\title{
Fostering urban transformations in Latin America: lessons around the ecological management of an urban stream in coproduction with a social movement (Buenos Aires, Argentina)
}

\author{
$\underline{\text { Martin Graziano }}^{1}, \underline{\text { Grecia Stefanía de Groot }}^{1,2}, \underline{\text { Laura Daniela Pilato }}^{1}, \underline{\text { María Laura Sánchez }}^{1}, \underline{\text { Irina Izaguirre }}^{1}$ and $^{\text {Haydée }}$. $^{1}$
} Pizarro $^{1}$

\begin{abstract}
Collaborative community-based approaches are proposed as a way to overcome the difficulties exerted by a broad range of social-ecological traps that emerge at the reconfiguration of social-ecological systems onto sustainable paths. Despite this, a deep examination of the social-ecological processes and interactions that constrain these approaches in different urban contexts is still necessary to improve their success. Latin American countries have institutional, political, and social characteristics that could constrain the pathways to sustainability in different ways from countries of the Global North, particularly in their metropolitan areas. Here, we present an experience (2015-2018) held in cooperation with workers of a social cooperative framed in an urban social movement from Argentina, related to the ecological rehabilitation of a highly degraded urban stream through the management of the riparian vegetation and the reintroduction of native macrophytes. The methodology involved a codesign approach based on a set of participatory actionresearch tools, together with resilience system analysis through causal loop diagrams, and three different interventions of a 200-m reach at the upstream area of the San Francisco stream (Buenos Aires, Argentina). The participatory diagnostic showed a strong negative effect of the current management guidelines on the riparian and aquatic vegetation, reflecting a positive feedback loop that reinforces this negative state, and revealed a hierarchical governance regime associated with the management of the watershed. Furthermore, it detected a strong motivation of local workers to generate transformative actions in terms of the sanitary and social-ecological improvements of the local habitat. The management actions showed a relatively high short-term survival of the macrophyte transplants (30-60\% in a period of $2-4$ months), displaying a strong spatial structure of the survival units, and downscaling to about $10 \%$ in the long term (6-12 months after interventions). A combination of biophysical and social processes related both to institutional and rigidity traps affected the survival of the transplants, reflecting the inertia of the current management programs to ecological improvements of the stream. In summary, the present work highlights the social-ecological constraints arising from transformative collective actions toward the ecological management of a stream at a highly vulnerable and bureaucratic urban context, with implications for socialecological urban transformations in Latin America and the design of effective participatory governance actions in alliance with local social movements.
\end{abstract}

Key Words: environmental governance; social movements; stream rehabilitation; urban social-ecological traps; water governance

\section{INTRODUCTION}

Reconfiguring social-ecological systems (SES) onto sustainable paths fostering transformative changes has been characterized as a messy and rocky enterprise (Olsson et al. 2006, Moore et al. 2014, Loorbach et al. 2017). Under the resilience framework, change in SES has been classically characterized by three interconnected phases: preparation, navigation, and consolidation (Olsson et al. 2004), where local awareness and microlevel experimentation are the main features that characterize the beginning of a sustainable transition (Pereira et al. 2018a). Many approaches designing and executing transformative spaces, e.g., niche experiments, urban living labs, T-labs, or seeds of good Anthropocene, are real-world examples of microlevel experimentation where collective action and collaborative learning take place to generate new pathways to sustainability (Bennett et al. 2016, Fuenfschilling et al. 2018, Pereira et al. $2018 b$ ). The success of these kind of interventions generally requires the breaking down of some features of the current system that constrain transformation, a somehow relegated aspect during the learning process of experimentation (Reyers et al. 2018). The identification and analysis of the social-ecological processes that could block or limit these collective-action initiatives are fundamental steps deep into the challenges and opportunities of local experimentation in the pursuit of sustainability (Enqvist et al. 2016, Baker et al. 2018).

Even though Latin America is a complex territory with huge biocultural and ecological diversity, the institutional, political, and social characteristics of its urban landscapes profoundly constrain the pathways to sustainability (Romero-Lankao and Gnatz 2013), in particular strategies of niche formation, experimentation, and consolidation (Ramos-Mejía et al. 2018, Wieczorek 2018). Latin American cities have a considerable persistence of hierarchical, multilevel management regimes (Child Hill and Fujita 2003), where top-down approaches generally designed and executed directly by governments, without any kind of participation of the local community at the decisionmaking process, predominate in the arena. Moreover, the persistence of political clientelism and marginalized or socially unattended areas can generate multiple obstacles for an efficient management of the urban space, promoting different kinds of social-ecological traps that contribute to a highly stable, but

${ }^{1}$ Departamento de Ecología, Genética y Evolución, Instituto de Ecología, Genética y Evolución de Buenos Aires (IEGEBA-UBA/CONICET), Facultad de Ciencias Exactas y Naturales, Universidad de Buenos Aires, Buenos Aires, Argentina, ${ }^{2}$ Present affiliation: Instituto de Investigaciones en Biodiversidad y Medio Ambiente (INIBIOMA-UNCO/CONICET), Río Negro, Argentina. 
undesirable, resilient state (Walker et al. 2006, Carpenter and Brock 2008, Enqvist et al. 2016).

In this sense, some authors have highlighted that current theories for sustainable socio-technical transitions should be improved by real-world experiences immersed in different urban settings (Frantzeskaki et al. 2016a, 2018), through "comprehensively approaching the more complex social aspects, particularly those of governance, while still keeping track of the material, technological side" of such innovation spaces (Ramos-Mejía et al. 2018:222). Thus, niche formation and consolidation in Latin American urban contexts needs to consider the specific institutional settings and the importance of social movements as "knowledge intermediaries" between the community and the academic world (Ramos-Mejía et al. 2018), just as civil society organizations have played protagonist roles in urban sustainability transitions in other parts of the world (Frantzeskaki et al. 2016b, van Welie and Romijn 2018). We will argue here that an alliance between scientists, social movements, and the local community could be a potential framework to deal with sustainability transformations in Latin America, explicitly assuming a bottom-up approach based on its democratic and socially inclusive value (Ludwig 2001, Rosendahl et al. 2015).

Meanwhile, streams on the urban landscape have suffered profound modifications leading to a process of ecological simplification over the last centuries, together with an increase of nutrients and pollutants drained into them, resulting in highly impacted streams with a great loss of structure and function (Walsh et al. 2005, Groffman et al. 2014, Peipoch et al. 2015). Water governance in Latin America, and particularly the management of urban streams, is done through centralized regimes in a top-down fashion (Anton 1993, Knieper and PahlWostl 2016, Woodhouse and Muller 2017). Different sociotechnical restoration approaches have been implemented over the last decades, ranging from a geomorphic point of view to a more ecological one, including the reintroduction of native species of fishes, macrophytes, and riparian vegetation (Larned et al. 2006, Palmer et al. 2007, 2014). In its infancy, there was an increased will to include the ecological and social drivers of restoration projects in an integrated approach, in addition with community expectations and real participation of the community (Stringer et al. 2006, Naiman 2013). In this sense, urban stream interventions made by practitioners in rehabilitation or restoration programs are quite common in some countries (Bernhardt and Palmer 2007, Palmer et al. 2007), but in Latin American cities these kinds of interventions are very rare (Capps et al. 2016). In turn, the implementation of collaborative and participatory approaches to stream rehabilitation have obtained quite disparate results regarding the ecological effectiveness of the restoration (Middleton 2001, Purcell et al. 2002, Eden and Tunstall 2006, Herringshaw et al. 2010). This marks the enormous potential for improvement if we posit these kinds of approaches under the framework of social-ecological experimentation and resilience analysis, e.g., understanding how social-ecological interactions determine the way that landscape and the ecological habitat is maintained and reconfigured (Alberti et al. 2018, Rocha et al. 2019).

We analyzed the establishment of a transformative urban space related to the ecological management of a stream located in the Metropolitan Area of Buenos Aires (AMBA, Argentina), in cooperation with local workers of a social cooperative framed in an urban social movement. We started with a collaborative learning approach where actors learn about each other, and about the management of the local habitat (Källström and Ljung 2005, Angelstam et al. 2013, Webb et al. 2018). We explored the implementation of a sociotechnical innovation that seeks to transform the current stream management guidelines of the region. Accordingly, the aims of the work were (1) to evaluate the social-ecological framework in which the work was supported, (2) to implement a simple and cost-effective protocol related to the cultivation of rooted native macrophytes and their subsequent transplanting at the stream reach, (3) to assess the effectiveness of the intervention related to the survival of the macrophytes transplants, and (4) to dissect the social-ecological processes that constrain the success of the ecological approach and the ways to circumvent it. We combined quantitative ecological analysis and a system perspective through causal loops diagrams to improve the identification of the social and ecological constraints arising at interventions. We finally discussed our experience in relation to the establishment and growth of transformative spaces in cities where there is no tradition of coproductive vision, focusing specifically in urban contexts of Latin America (van Kerkhoff and Lebel 2015).

\section{CONTEXT AND METHODS}

\section{Socio-environmental background of the Metropolitan Area of Buenos Aires, Argentina}

The Metropolitan Area of Buenos Aires (AMBA) is the main urban conglomerate of Argentina, with more than 13 million inhabitants (INDEC 2010). Administratively, it comprises 40 municipalities and the Autonomous City of Buenos Aires. Within the AMBA there are four main watersheds with numerous rivers and lowland streams that cross the area to finally end at the Río de la Plata Estuary (Fig. 1). The relatively fast and uncontrolled growth of the population in the AMBA over the last 60 years has provoked an intensified use of the land with strong consequences on environmental quality, mainly on aquatic environments (Öberg et al. 2014). Watercourses have been highly modified, with channelings, adjustments, deviations, and partial or total piping, resulting in strong ecological simplification of main habitats (Capítulo et al. 2010). In turn, because investments in sanitary infrastructure did not accompany the growth of the metropolis, streams and rivers are high impacted by untreated sewage and domestic effluents (Cirelli and Ojeda 2008, Öberg et al. 2014), with high levels of organic and microbiological contamination detected conspicuously in all basins (Magdaleno et al. 2001, Castañé et al. 2006, Vilches et al. 2011). These features, added to the frequent flooding events that occur in many localities surrounding streams and the persistence of microgarbage points in the riparian zones, lead to a negative socio-environmental perception of these environments (Guida Johnson et al. 2015). Despite this, during the last decades several civil society organizations and social movements have emerged throughout the AMBA looking to improve their habitat and working conditions, particularly in locations where the lack of sanitary/ basic infrastructure, socioeconomic development, and good environmental quality is commonplace (Svampa and Pereyra 2003, Scheinsohn and Cabrera 2009, Merlinsky et al. 2012, Pereyra et al. 2015). 
Fig. 1. Map showing the Metropolitan Area of Buenos Aires, including its administrative subdivisions (in grey). The area covered by the four main basins of the region are depicted with colors, including their stream network topology in light blue. The inset shows the locality of Claypole (in orange), at the Almirante Brown District, together with the course of the San Francisco stream flowing to the Rio de la Plata Estuary.

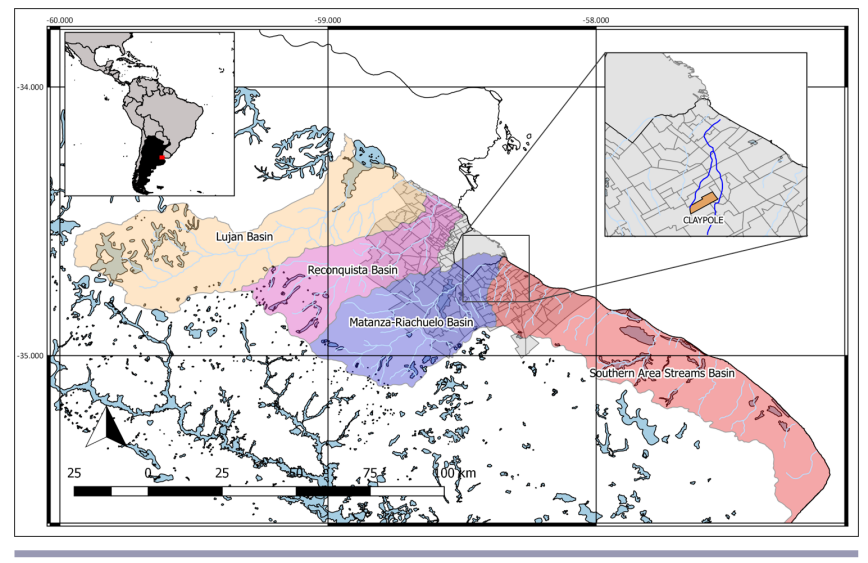

Local background for place-based action-research

The San Francisco creek, belonging to the stream basin of the southern area of the AMBA, is categorized as a first-order lowland stream with a total length of 15 kilometers that flows to the Río de la Plata Estuary after its confluence with Las Piedras stream (inset Fig. 1). It is piped at its origins at the peri-urban area of the Almirante Brown District, emerging to surface at the urban location of Claypole (Lat: $34^{\circ} 49^{\prime} 14^{\prime \prime} \mathrm{S}$; Long: 58 $21^{\prime} 45^{\prime \prime} \mathrm{W}$ ), with an estimated flow of $20-30 \mathrm{~L} / \mathrm{sec}$ and a mean wetted width of 2-5 m (Efron 2015). Previous studies have shown a high degree of organic and microbiological pollution across the stream length, together with evidence of environmental deterioration of the riparian and aquatic environments (FREPLATA 2004, Efron 2015, Elordi 2016), although its headwater area shows a better ecological state than downstream, where the major population pressures are concentrated (Efron et al. 2014, Efron 2015, Elordi 2016; Appendix I). In turn, the city of Claypole presents some worrisome socio-demographic characteristics (Table 1). With a total number of 19,935 households, only $2 \%$ of them have sewage systems and $23 \%$ have a potable drinking water supply. There is also a high number of homes with unsatisfactory basic needs (Table 1). These features configure a scenario commonly found in many urban and peri-urban areas of Latin American cities (Hardoy and Pandiella 2009, Capps et al. 2016).

In this context, during the years 2015-2018 we established a collaboration process with workers of a social cooperative (named Mirabal Cooperative), which is part of a national civil society organization named "Frente de Organizaciones en Lucha" (FOL; Fig. 2a). This urban social movement has two community centers in Claypole (Mirabal and Galpon cultural centers; Appendix 1), both located adjacent to the San Francisco stream. Besides its main role related to the social organization of the poorer people of the region to improve their living and working capacities, for several years the FOL has shown interest in promoting sustainable and ecological practices of the environment, with special emphasis on the water quality of the San Francisco stream and its surrounding habitat. The social cooperative included inside the structure of the organization was born through the emergence of the National Assistant Program called "Argentina Trabaja" ("Argentina Works"), where people without a formal income and in a disadvantaged socioeconomic condition had the opportunity of associating with cooperatives carrying out public work on infrastructure and/or sanitation activities in their communities (Natalucci 2012). The activities developed by Mirabal Cooperative were part of the cleaning and sanitation programs executed through the municipality of the district, with 12 hours of work per week. During the development of the project some people had to leave the project and other people joined, maintaining a staff of approximately 10 workers during the entire period. At the end of 2015, when the political administration of the nation changed, the Argentina Trabaja Program was gradually abandoned and finally shutdown by the beginning of 2018 .

Table 1. Claypole's socio-demographic features. Main socioeconomic indicators focusing on the analysis of housing characteristics (housing habitat conditions) and basic services and sanitation (water supply and sewage). The indicator of unsatisfactory basic needs is an indicator of poverty measurement, referring to the needs of decent and healthy housing. Socio-demographic factors undoubtedly reveal a local context associated with poverty and social exclusion.

Socio-demographic characteristics (Claypole)

\begin{tabular}{lc}
\hline Population / $\mathrm{N}^{\mathrm{o}}$ of households & 73,187 inhab / 19,935 homes \\
Homes with sanitary sewer cover & $2.1 \%$ \\
Homes with public water supply & $23.5 \%$ \\
Homes with unsatisfactory basic needs & $12 \%$
\end{tabular}

\section{Codesign and analysis of the social-ecological framework}

A general scheme of the entire coproductive process is shown in Figure 2b, highlighting three main phases: codesign, implementation of interventions, and evaluation. During the first four months of the project, we provided a codesign atmosphere through the engagement in several bimonthly meetings with three main objectives in mind: (1) to enforce the mutual knowledge and confidence between the partnerships (workers of the social cooperative and our field group of researchers), (2) to dialogue about the social-ecological framework of our work and the conceptualization of the proposed ecosystem-based strategy to improve the stream habitat, and (3) to cocreate the working schedule considering the main stages of the proposed work: cultivation and propagation of macrophytes, the interventions per se, and a general monitoring scheme. To this aim, we established a participatory action-research approach (Parkes and Panelli 2001, Chevalier and Buckles 2013) that included several activities: participatory mapping of social actors, field observations of stream habitat, focus group discussions stimulated by multimedia videos (cooperative's management practices on local streams), presentations of academic information, documents of official web sites (e.g., regulations of management programs of streams of the Buenos Aires Province), 
Fig. 2. Schematic diagram of the coproductive process. (a) Depicts the three main components of the participatory action-research: the local territory, the academic actor, and the community actor. A general scheme of the entire coproductive process is shown in (b), highlighting the three main phases: codesign (green), preparation and implementation of the interventions (orange and yellow, respectively), and the evaluation of the process (pink).

a

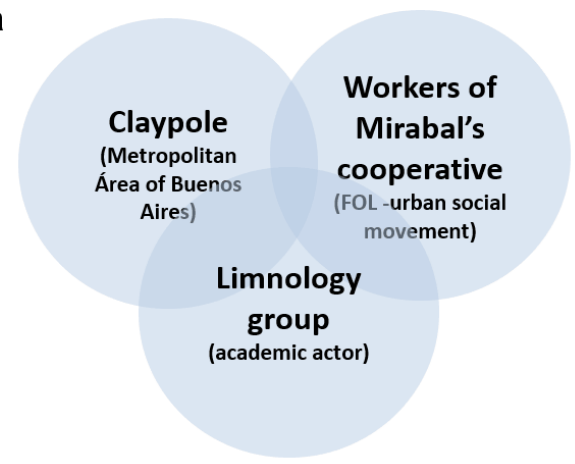

b
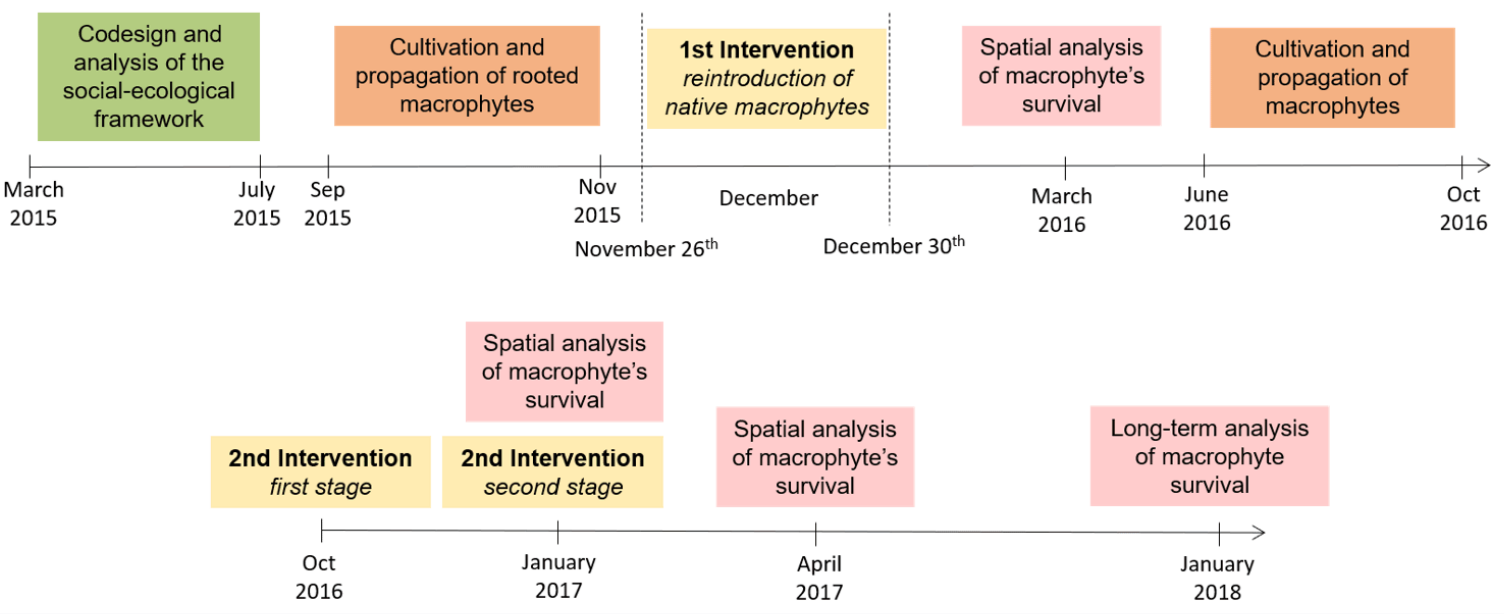

and media publications. The activities focused on the identification of local environmental issues associated with the San Francisco stream, the architecture of the governance system related with the management of streams, and a discussion about the importance of the native aquatic and riparian vegetation as a main component of the ecological subsystem, in opposition to the hegemonic engineering vision of stream and river management. Qualitative data documenting the perceptions of the local workers were registered together with a synthesis of each workshop (for more details see Appendix I). Data was codified for analysis in four main themes: governance system, socialecological interactions, socio-environmental perceptions, and motivations for intervention.

\section{System analysis}

From the knowledge gathered in previous meetings related to management practices, water quality issues, local perception of the environment, and academic knowledge of the structure and function of lowland streams, we applied system analysis (Sterman 2000), particularly causal loop diagrams, to analyze the local social-ecological interactions found around the San Francisco stream. We explored specifically the identification of positive and negative relationships between the main components of the system (Chapin et al. 2009, Rocha et al. 2019), and the occurrence of reinforcing feedback loops in the system dynamics (Enfors 2013, Hänke et al. 2017) that could explain the persistent maladaptive state observed in relation to the ecological and sanitary integrity of the stream. The resulting causal diagram loops were discussed with local participants of the cooperative in order to validate the analysis following a participatory approach (Basco-Carrera et al. 2017).

\section{Analysis of motivations}

We finally conducted a forced-options activity with the members of the cooperative to explore and reflect on the personal and collective motivations of the present project, given that at the meetings some workers did not feel confident to speak openly. We provided eight predefined options based on information gathered in these meetings (Appendix 1), classified and selected based on the following categories: aesthetic motivations, sanitary (health) motivations, social, ecological, and biocentric motivations. All the participants (including academic actors) had to rank the options based on their own motivations and share with the others. Answers given by each participant were categorized by the relative importance from 1 (most important) to 7 (least important). Only the responses obtained from the local actor $(n=8)$ were used given the aim of the activity. 


\section{Implementation and analysis of an ecosystem-based intervention} Pampean streams with low anthropic impact are distinguished by their low current velocity, the presence of natural high levels of phosphorus and nitrogen dissolved, and a general absence of a riverine forest that determines a high incidence of solar radiation, impacting on a high net primary productivity (algae and macrophytes; Feijoó and Lombardo 2007, Capítulo et al. 2010). In this sense, macrophytes play a key role in structuring the rest of the aquatic biological communities, such as macroinvertebrates and biofilm communities (Giorgi et al. 2005). On the other hand, the elimination of the aquatic vegetation is one of the main effects of the ecological simplification exerted because of the urbanization process and current management practices (Paz et al. 2018). For this reason, we use an intervention approach based on the ecological functioning of these streams that involved the reintroduction of native macrophytes to generate environments with greater diversity and abundance, with the aim of promoting ecologically sustainable management practices of the aquatic environment.

\section{Macrophyte cultivation}

We selected aquatic floating-leaved macrophytes for reintroduction in the stream based on previous regional works about native species (Cabrera and Fabris 1948, Feijoó and Lombardo 2007, Efron et al. 2014). Floating-leaved macrophytes were selected for their better stability of flow variations compared with freefloating macrophytes, with less risk of being pulled off from the stream-bank in periods of flood. To favor an increase in the richness of native macrophytes present at the stream, we selected species not currently present in the stream: Ludwigia peploides, Hydrocleys nymphoides, and Nymphoides indica, all of them reported as present in low impacted Pampean streams (Cortelezzi et al. 2012). Initial samples of these macrophytes were acquired in local nurseries in the province of Buenos Aires and were propagated in plastic trays (Riis et al. 2009).

We designed a simple cultivation protocol in monospecific plastic trays of $25 \times 20 \times 5 \mathrm{~cm}$ for Ludwigia peploides, and rubber pots of $10-15 \mathrm{~cm}$ of diameter in the case of Hydrocleys nymphoides and Nymphoides indica. They were arranged in pools filled with water so that trays and pots were completely submerged (Appendix 1). Special emphasis was placed on keeping low levels of turbidity and algae growth throughout the cultivation process, because these factors condition the penetration of light and therefore the growth of the plants. Commercially available fertile soil was used as substrate. Plants were cultivated at the experimental field of the university by academic actors. This process was carried out during the period of August-November for the intervention executed in 2015-2016 (end of winter and spring season), and during the period of June-October for the intervention held in 2016-2017 (winter-spring season).

\section{Macrophyte transplants and maintenance of the riparian environment}

During the period of 2015-2018, we performed two collaborative community-based interventions in 2015 and 2016-2017 to reintroduce native macrophytes not currently present at the stream and analyze their survival capacity (Fig. 2b). We worked in a 200-m area of the San Francisco stream where the squad had their working activities of cleaning and sanitation. For both interventions, prior to the macrophyte transplant, we proceeded to weed the riparian zone to reduce the competition between naturally occurring macrophytes and other plants that are not typical of that environment (Van Driesch and Center 2013), and to collect the trash accumulated on the streambank and the instream area. The transplants of cultivated macrophytes were carried out in sites moderately protected from the stream current and with less slope, using both the substrate of the trays and the sediment of the stream, predominantly clay, as a cementing agent and supplemented with fertile soil when necessary. During the first intervention (December of 2015), we transplanted a total of 50 experimental trays ( 27 trays of $L$. peploides and 23 trays of $H$. nymphoides). For the second intervention, we transplanted 64 trays (31 trays of L. peploides, 24 trays of $H$. nymphoides, and 9 trays of $N$. indica) during the first stage (October-November of 2016), including a reinforcement of 21 experimental trays (10 trays of $L$. peploides, 2 trays of $H$. nymphoides, and 9 trays of $N$. indica) during a second stage of the intervention (January of 2017). For both interventions, a pruning maintenance was carried out in those areas where the coverage of macrophytes present in the stream was higher than $70 \%$ (mainly of a pre-existent macrophyte, Hydrocotyle ranunculoides) to improve the water flow and replanted in sectors where it was absent. All the transplant sites were georeferenced with the aim of monitoring the survival of the macrophytes.

Finally, we conducted periodic meetings after each intervention to analyze the preliminary results of the work, to know the feelings of each worker about the growth of the aquatic plants, and to analyze the factors that conditioned the success of the proposed intervention. Qualitative data (meeting reports) was recorded about these meetings. A multimedia video of the interventions can be accessed from http://y2u.be/bqtQbH0yd30.

\section{Spatial and statistical analysis}

In order to explore environmental factors that could affect the survival of the transplants, we use geolocalized data of transplanted macrophytes to establish the survival condition of each one. Original transplanted macrophytes within a $3-\mathrm{m}$ area of a survival geolocalized point were considered survivor macrophytes. Otherwise, we defined mortality as the lack of observation of an experimental unit previously georeferenced, which could be because of detachment or death of the transplanted macrophyte. To compare across intervention sites, we obtained meteorological data of daily air temperature and precipitation from the nearest meteorological station of the National Meteorological Service $(15 \mathrm{~km}$ away at the location of Ezeiza, Province of Buenos Aires, accessed from https://www. wunderground.com). Moreover, to analyze spatial patterns in macrophyte survival at intervention sites, a joint count analysis was performed (Mathur 2015). The statistical analysis allowed us to detect patterns of aggregation of survival and mortality of experimental units. We used a k-neighborhood connectivity matrix that recovers the structure of the local urban space, such us constructed canals, street bridges, and the pluvial drainage system. A permutation analysis was performed $(\mathrm{N}=999)$ to detect significant differences with respect to the null hypothesis of random structuration of survival. Finally, a Fisher Exact Test was performed to analyze the occurrence of significant differences in survival between species of macrophytes on each stage of intervention. All statistical analyses were performed with the $\mathrm{R}$ software, package spdep (Bivand et al. 2013, R Team Core 2018). 
Table 2. Governance architecture of active institutional programs for the cleaning and sanitation of urban streams at the Metropolitan Area of Buenos Aires during the period 2015-2017. Basin delimitation for each program and main actors related with the supervision and execution of activities depicts a complex hierarchical structure at multiple administrative levels and some unifying features at program execution.

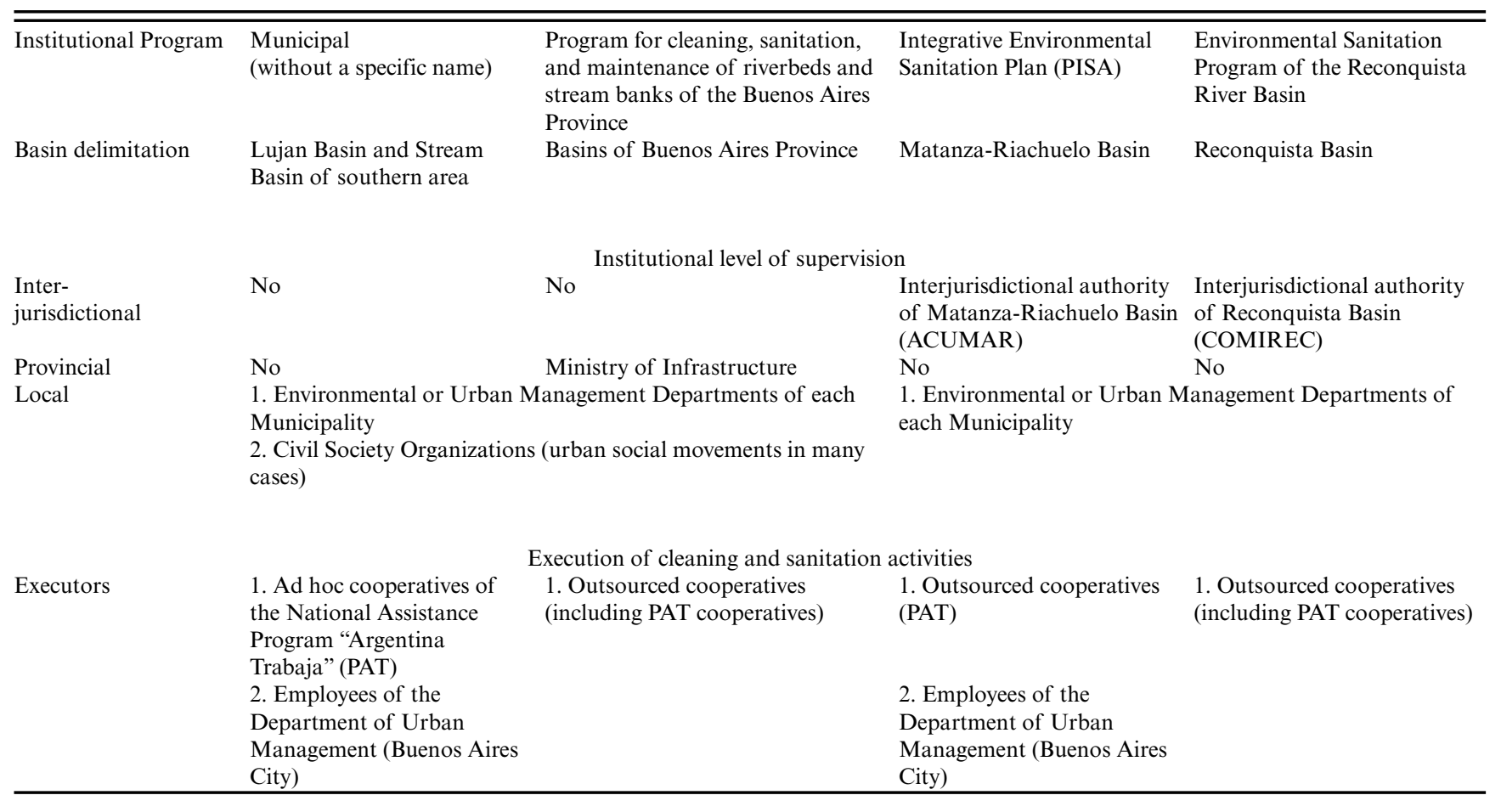

\section{Social-ecological analysis of interventions}

With the aim of analyzing the set of social-ecological constraints that emerged and blocked the success of the interventions, we identified the potential effects of the reintroduction of macrophytes in the dynamics of the system, analyzing the positive and negative feedbacks emerging from the proposed transformation. We also identified the factors or processes that blocked its success, analyzing the main affected relationships of the system and integrating the results obtained from the previous qualitative and quantitative analysis.

\section{RESULTS}

\section{Social-ecological framework and the architecture of the governance system}

The diagnosis of the broad governance context distinguished four different institutional programs and actors playing a role related to the cleaning and sanitation management of streams at the regional scale, spanning the major basins of the AMBA (Table 2). Two of these programs were coordinated by interjurisdictional administrations and encompassed the basins that have the most public pressure and visibility, along with a greater population exposed to the related environmental and health problems of the region (Matanza-Riachuelo and Reconquista basins). The other programs are subjected to strong fragmentation related to the institutional supervision at the provincial and municipal level, including the superposition of activities in a same basin. They include the streams and rivers of the Lujan Basin and the streams that flow through the south region of the AMBA, including the San Francisco stream. Despite these differences, we found two main common features that go through all the programs: (1) one of the main executors of the management actions were workers of social cooperatives, (2) the management guidelines were similar across programs. In first place, the vast majority of the social cooperatives that work on these sanitation programs were included at the National Assistance Program Argentina Trabaja, and in many cases, they were outsourced to accomplish the activities of a specific program (accounting for a salary plus and better infrastructure resources). On the other hand, the management guidelines strictly focused on sanitary and engineering aspects without considering the ecological features of streams, or even more, the social-ecological status of the basin. These guidelines include the elimination of all the aquatic and riparian vegetation, leaving in many cases a high amount of soil exposed to fluvial erosion.

At the local level, we found a considerably dense network of interactions (Fig. 3), mostly impacting in some way on the ecological integrity of the stream, and with the presence of other social actors who benefit through cultural or recreational activities (local schools, neighborhoods, and cultural centers). For example, local schools generally organize several activities around the stream during the year, including the plantation of a forest at the beginning of the spring season. In turn, some neighborhoods collect worms for recreational fishing or use the riparian zone to feed their horses. On the other hand, anthropogenic drivers of change are mostly related with the management of the stream and 
neighborhood's behavior regarding the final disposition of garbage around (and inside) the stream. Cooperative workers recognize that the local management of the San Francisco stream, as a provincial resource, is under the administration of municipal and provincial governmental institutions, and that the stream faces considerable impact from the nonexistent local sewerage cover and the increased drainage networks that drain into it. A similar problem occurs with garbage, where local programs are ineffective in raising people's awareness of not throwing trash in the stream. We also found a spatial overlap of cleaning activities with the other cooperative ("La Fabrica," Fig. 3), supervised at the provincial level (Table 2). In addition, the municipality of Almirante Brown performs the weeding of the riparian vegetation through its Urban Management Department.

Fig. 3. Local social-ecological framework depicted from a participatory approach. Government institutions, local schools, social cooperatives, civil society organizations, and individual neighborhoods compose a wide social network that interacts with the stream, many of them as anthropogenic drivers of change, and some of them benefiting from it mainly through cultural ecosystem services.

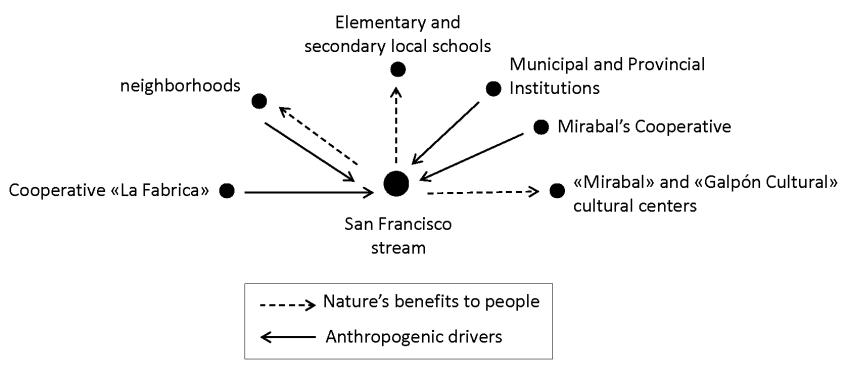

According to this scenario, we analyzed the social-ecological dynamics of the system to understand the interactions between the ecological and social factors related with the ecological and sanitary integrity of the stream. We found the occurrence of multiple reinforcing loops (positive feedback loops), driven mainly by the current management practices, which impact on the ecological integrity of the system, intensifying a negative socio-environmental perception, and thus reinforcing the hegemonic hydraulic vision of the management guidelines (Fig. 4). Current management practices reduce the presence of aquatic vegetation on the stream, directly affecting the biogeochemical processes that they exerted. These practices increase the stream water flow favoring flashy hydrologic dynamics that increase the frequency and intensity of disturbances, and increase the concentration of nutrients, toxins, and pathogens by an inefficient regulation of the final garbage disposition and the discharge of domestic and sewage effluents into the stream. These features, clearly observed and analyzed during our meetings and participatory activities, elicit a set of interacting reinforcing loops that give place to a potential social-ecological trap dynamic.

Taken all together, the diagnosis phase of the coproduction scheme set up a basis for understanding why we are trying to establish alternatives to the current management practices, and favored a community- and ecosystem-based management of the stream. An analysis of the motivations presented by the workers of the cooperative indicated that sanitary and eco-community motivations were the most important aspects that this kind of management could provide, while secondary aspects included more biocentric, socio-community, or aesthetic features of the project (Fig. 5). Sixty-three percent of the answers placed the improvement of the stream as a means of improving their health status as the first level of importance, followed by the collective improvement of the neighborhood environment, and the importance of leaving a better environment for future generations. As a middle level of importance, biocentric positions emerged, such as the improvement of the stream to allow other living beings to live again on it. It is interesting to note that the last option ranked by the workers engaged in the project was an aesthetic motivation, given that the persistence of trash in the environment is one of the main concerns.

Fig. 4. Simplified local social-ecological dynamics around the San Francisco stream. Causal diagram loop analysis shows the emergence of multiple reinforcing feedback loops mainly driven by the current management guidelines for stream management. Arrows delineate the causal relationship between social or ecological elements, and signs (+ or -) reflect the kind of interaction (positive or negative) between them. Central to this work is the reinforcing nature of the negative impact of current practices over the aquatic vegetation, leading to higher nutrient, pathogen, and toxin concentrations, decreased ecological and sanitary integrity of the stream, degradation of the socioenvironmental perception by neighborhoods, and consequently a reinforcement of the current management guidelines.

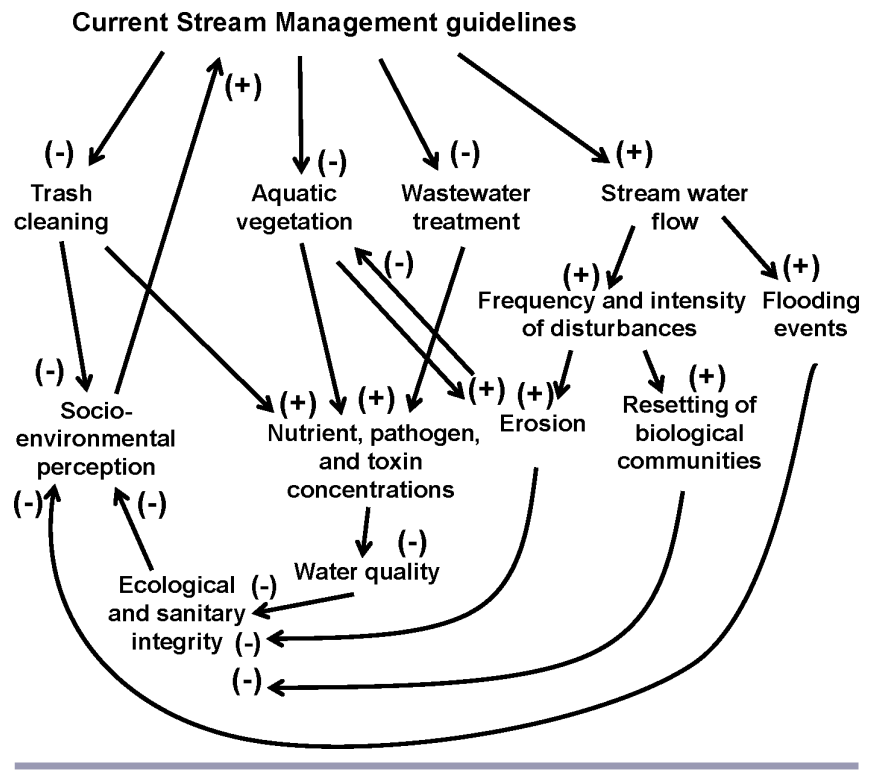

\section{Analysis of social-ecological constraints to ecosystem-based interventions}

Workers participated successfully on each intervention even on longer than usual working days (Figs. 6a-c). A working day was about eight hours for about an 80-m stream reach, reintroducing around 20-25 units per day jointly with weed cutting and trash collecting. During interventions they learned which were the best practices for successful transplants and weed cutting, taking care to not cause soil erosion but harvesting any excessive growth of aquatic or terrestrial vegetation. One of the most significant 
Fig. 5. Motivation analysis associated with the community-based ecological management of the San Francisco stream. Workers ranked in order of perceived importance several options related with different aspects of the potential impact of community-based ecological management. The spider graph shows the relative importance of each predefined option based on a frequency analysis. The results show that sanitary and eco-community aspects (e.g., to collectively improve the environment; to leave a better environment for our kids) were more relevant for cooperative workers to be engaged in the proposed initiative.

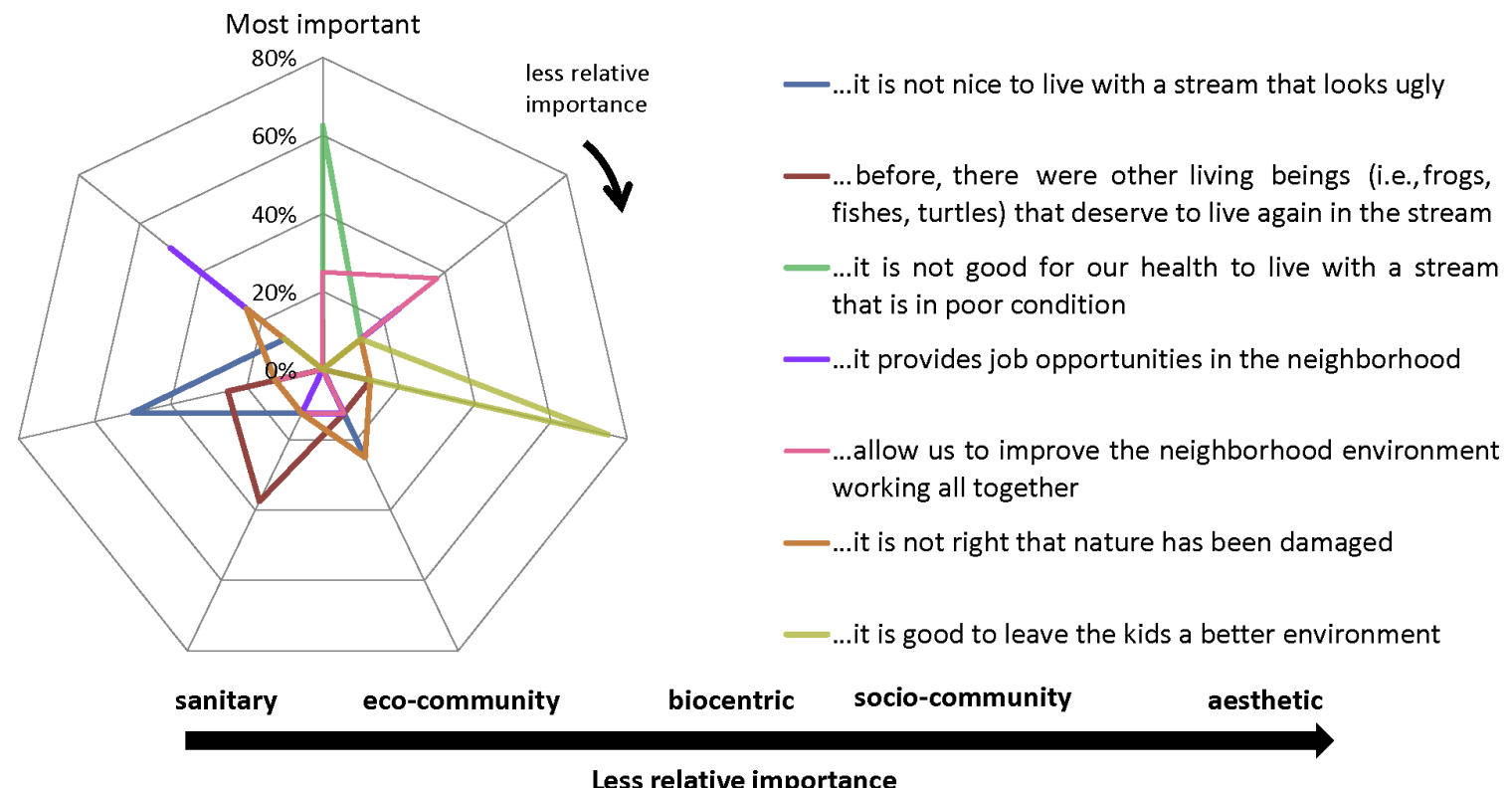

Less relative importance

expressions of happiness during the work was related to the visualization of the growth and flowering of macrophytes during monitoring observations, which grew up considerably a few weeks after they were transplanted (Figs. 6d-e).

Fig. 6. Local interventions performed at the San Francisco stream reach with workers of the Mirabal cooperative. Photographs depict different activities performed at interventions (a-c). After several weeks, aquatic macrophytes grew and flourished successfully, e.g., Hydrocleys nymphoides (d) and Ludwigia peploides (e).

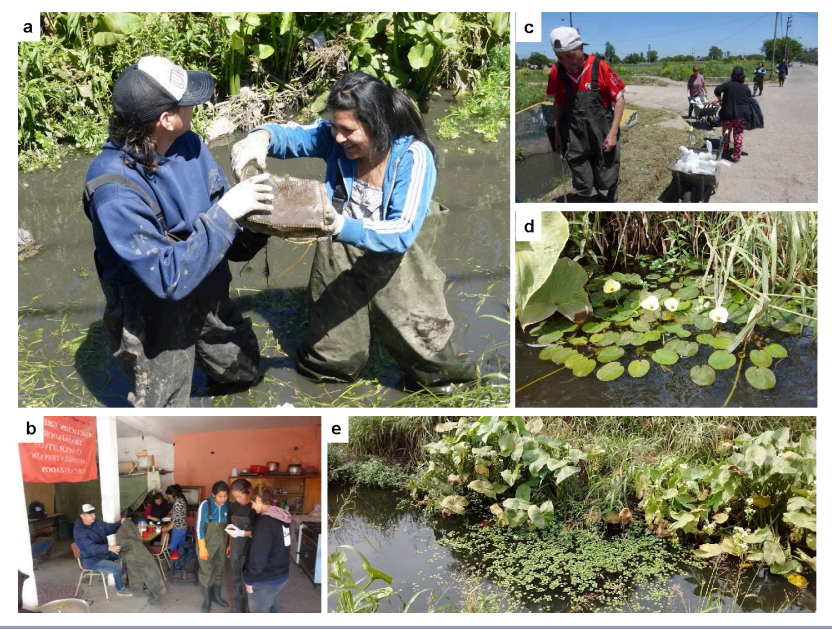

During the first intervention in 2015-2016, we found both social and environmental processes affecting the short-term survival of transplanted macrophytes (Table 3). Three months after transplantation we found a low percentage of survival (only $28 \%$ of transplants survived), mainly because of environmental conditions such as a significant flooding event that occurred one and a half months after the intervention (see precipitation events in Fig. 7, top-right panel), which caused the accumulation of macrophytes at crossing bridges. The sporadic work of another cooperative, La Fabrica, diminished greatly the survival to $8 \%$ after two weeks of the first monitoring event, opening the opportunity to have several meetings with the coordinators of this cooperative and institutional supervisors to limit the work of this squad on the intervention area. Moreover, we discussed with them the negative effects of removing the aquatic and terrestrial vegetation on the water quality of the stream. Finally, long-term survival was extremely affected by these events, and after 10 months of intervention only one transplant remained at the stream. A spatial analysis of the survival units before the work of La Fabrica cooperative revealed a significant aggregation pattern of survival (Z-score: $2.13 ; \mathrm{p}<0.05$ ), reflecting the fact that some locations were more prone to the survival of transplanted macrophytes (Fig. 7, top-left panel). Moreover, although a differential survival of some macrophytes was not observed $(p>$ 0.1 ; odds ratio $95 \%$ confidence interval: $0.126-2.22$ ), there was a significant effect of macrophyte species on the spatial pattern of aggregation: Ludwigia peploides had a significant spatial aggregation pattern ( $Z$-score: $3.30, \mathrm{p}<0.05)$, not observed in the case of Hydroclyes nymphoides (Z-score: $0.46, \mathrm{p}>0.1$ ). 
Table 3. Macrophyte's survival at interventions during the 20152018 period. Short-term and long-term effects revealed the main social and ecological processes that constrain the effectiveness of the local interventions.

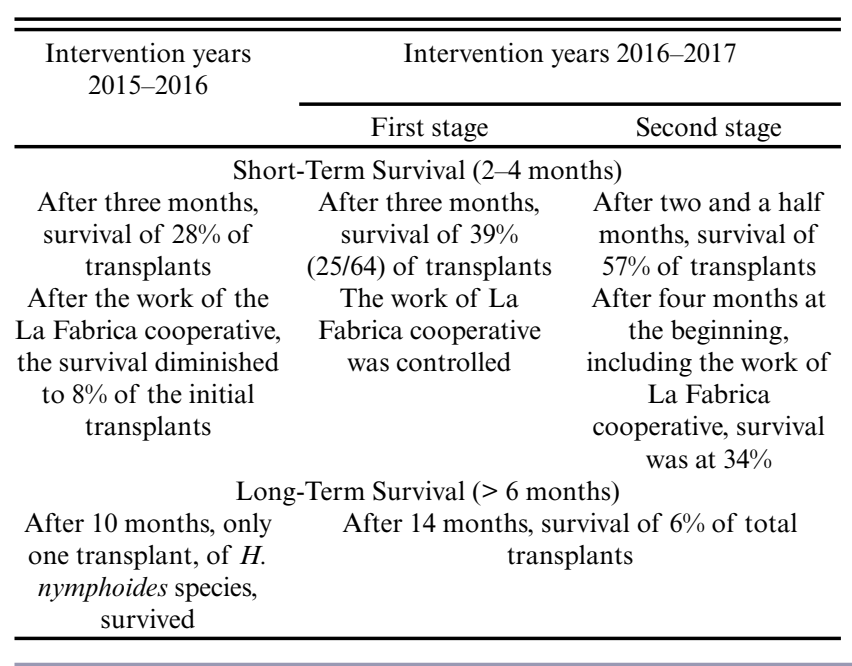

Fig. 7. Short-term effects of environmental constraints affecting macrophyte survival. Maps on the left show the geolocalization of experimental units according to the species transplanted (color code) and its survival condition during the period of analysis (black border: survivor; without border: no survivor). Right plots show the temporal variations in daily temperature and precipitation that could affect the survival of macrophytes. Grey boxes denote the period of analysis depicted in each map. Maps show a clear pattern of spatial aggregation of transplant's survival and mortality.

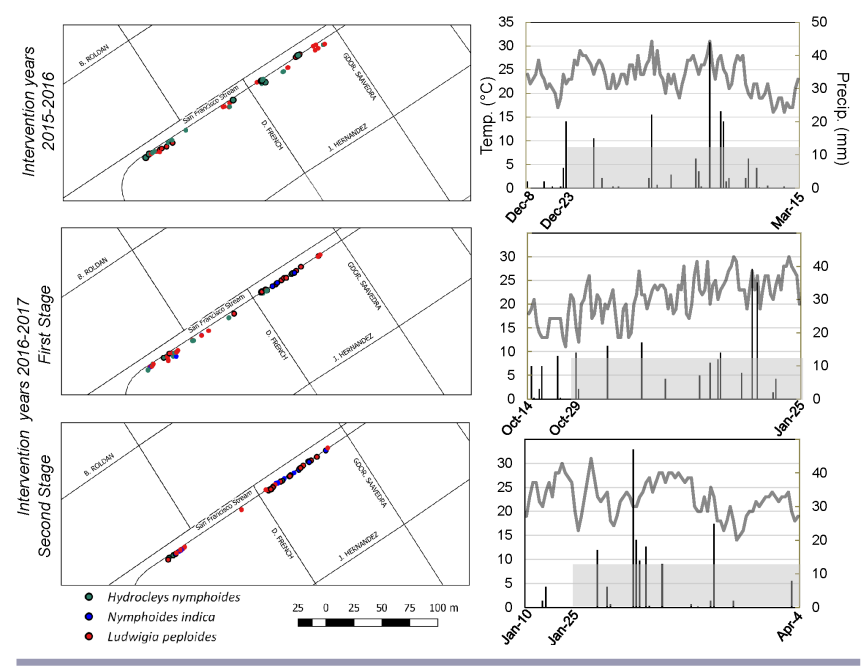

In order to confirm the patterns found and to try to improve and replicate the interventions made, the next year we performed a couple of interventions during the spring and summer seasons of 2016-2017. We obtained in general terms an increased percentage of macrophyte survival (Table 3), maybe reflecting a better understanding of the transplantation process, e.g., given the results of the first intervention, we avoided some specific locations near bridges. Moreover, the work of La Fabrica cooperative was, although not completely, satisfactorily controlled (taking care of not removing aquatic vegetation). Short-term survival was above $30 \%$ in a period of four months, with a survival of $57 \%$ after two and a half months. On the other hand, after more than a year only $6 \%$ of transplanted macrophytes survived. The spatial analysis reflected the effects of environmental processes that affected the short-term survival of macrophytes (Fig. 7, middle and low panels), exhibiting a spatial aggregation pattern for survival and mortality at both stages $(Z$-score $>1.96$ and $\mathrm{p}<0.05$ in all cases). We also found a differential mortality of $H$. nymphoides compared with the other macrophytes at stage 1 of the intervention (Fisher Exact Test, $\mathrm{p}<0.05$ ), possibly reflecting the fact that this macrophyte was transplanted more conspicuously in the first $100 \mathrm{~m}$ of the reach where we observed a clear pattern of mortality aggregation (see Fig. 7, middle-left panel) and clear evidence of streambank erosion.

Finally, and based on the results, we synthetized the socialecological constraints found in terms of the distinction between several processes that affected the success of a community-based ecological management initiative based on the reintroduction of macrophytes to revitalize the stream (Table 4, Fig. 8). In the first place, institutional fragmentation and rigidity directly affected the survival of transplanted macrophytes because of the superposition of activities between cooperatives of different programs and supervised by different actors (municipal and provincial authorities). Second, the socioeconomic context was a constraint to the community-based management per se, expressed in workers' difficulties to be fully engaged during the last period of intervention, and also in some limitations found for the maintenance of the cleaning activities and the stability of the working staff because of the highly insecure labor conditions (low salaries, insufficient materials and equipment). Last, increased erosion facilitated by the current management practices affected the biophysical control of macrophyte survival, promoting the detachment of macrophytes transplanted in regions of the stream where the discharges of water were more important, e.g., pluvial drainage channels. A causal diagram loop shows the relationship between these processes and the components of the socialecological dynamics, elucidating the interactions mainly affected by each constraint (Fig. 8). Finally, we provide some learning outcomes derived from the work that seeks to foster communitybased social-ecological transformations at the San Francisco stream (Table 4).

\section{DISCUSSION}

We analyzed the establishment of a social-ecological transformative urban space, coproduced with an urban social movement, around the ecological management of the San Francisco creek, located in the Metropolitan Area of Buenos Aires, one of the main populous cities of Latin America. Based on a participatory diagnostic and integrating a diverse set of types of knowledge, we codesigned an ecosystem-based intervention in order to break the undesirable social-ecological dynamic identified in the system, which also revealed a hierarchical governance regime associated with the current management of the watershed. The combined approach of quantitative ecological analysis and a resilience system perspective allowed us to identify 
Table 4. Learning outcomes from the collaborative experimentation initiative. Social-ecological processes that affect community-based ecological management of the San Francisco stream, and several actions to foster social-ecological transitions at the urban stream.

\begin{tabular}{ll}
\hline \hline Social-ecological constraints & Learning outcomes \\
\hline $\begin{array}{l}\text { Institutional fragmentation and } \\
\text { rigidity }\end{array}$ & $\begin{array}{l}\text { Foster multistakeholder } \\
\text { participation within a polycentric } \\
\text { governance framework }\end{array}$ \\
$\begin{array}{l}\text { Insecure labor and socioeconomic } \\
\text { conditions }\end{array}$ & $\begin{array}{l}\text { Engage in a more powerful social } \\
\text { network to mobilize resources } \\
\text { toward the community }\end{array}$ \\
$\begin{array}{l}\text { Biophysical control of macrophyte } \\
\text { survival }\end{array}$ & $\begin{array}{l}\text { Favor alternative stormwater } \\
\text { management systems and innovative } \\
\text { technologies for macrophyte } \\
\text { retention }\end{array}$ \\
\hline
\end{tabular}

a combination of biophysical and social processes related both to institutional and rigidity traps affecting the efficacy of the socio-technical innovation, reflecting the inertia of the current management programs to ecological improvements of the stream. Moreover, the approach allowed us to identify several learning outcomes with implications relative to governance and sociotechnical aspects that could foster the breakdown of the socialecological constraints that emerged from the work. We believe that our approach and conclusions are also relevant to the establishment and growth of transformative spaces in urban socio-political contexts of Latin America and other parts of the world. The discussion will develop on these implications.

\section{Urban traps in Latin America's watershed governance:} implications for socio-technical transitions

We identified a system dynamic that resembles the existence of a social-ecological trap, which causes the persistence of a current maladaptative state of the stream (Laborde et al. 2016). Among the diversity of definitions behind the concept of a socialecological trap (see Cumming 2018, Haider et al. 2018), there are two aspects highlighted by the authors at the core of the system: an undesirable persistent state, and a reinforcing mechanism that imposes difficulties in leaving it (Haider et al. 2018). According to this, we have evidence in favor of our assertion: the persistence of a negative perception of the stream habitat by the local community, quantitative evidence related to the habitat and water quality of the stream (Efron et al. 2014, Efron 2015, Elordi 2016), and the persistence of the undesirable state despite our disruptive intervention. We propose that one of the key external factors that maintains the described social-ecological dynamic is the governance architecture, resembling many aspects of a commandand-control scheme (Holling and Meffe 1996, Cox 2016). This factor is reflected in the presence of institutional fragmentation within the governance system, and some rigidity aspects related with the hegemonic hydraulic model of stream management. Rigidity traps and institutional traps were confirmed in many related systems with water governance in other countries, e.g., in Bangalore, India (Lebel et al. 2011, Boonstra and De Boer 2014, Enqvist et al. 2016). Moreover, poverty conditions in such contexts also contributes to a disadvantaged background that affects the consolidation of any transformative space (Enfors and
Fig. 8. Hypothetical changes in social-ecological dynamics regarding the reintroduction of macrophytes at the San Francisco stream, and specific social-ecological constraints found in our work (black boxes). Institutional traps (fragmentation and rigidity) and the socioeconomic context explicitly affected the attempts to successfully reintroduce macrophytes at the local reach, together with a negative impact of the current management of hydric excedents (through increased erosion) over the biophysical control of macrophyte's survival. External drivers are outlined in red.

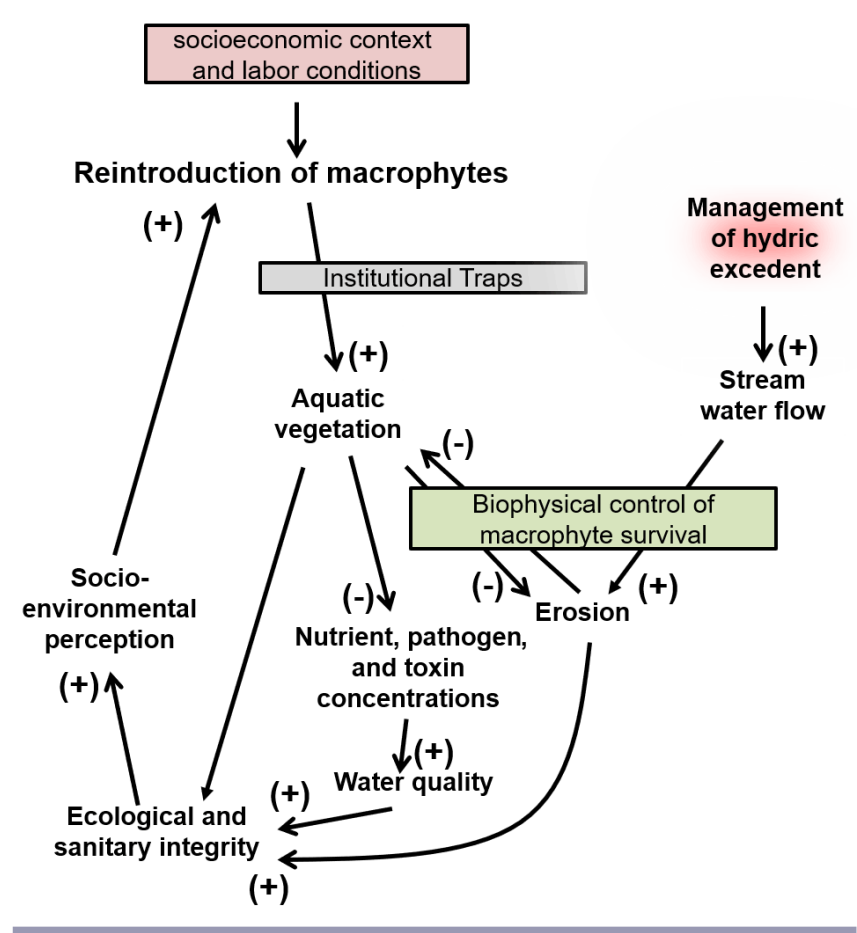

Gordon 2008, Cinner 2009, Brown 2016). The existence of a poverty trap in our context can possibly be analyzed as another factor promoting the persistence of the negative state (Bowles et al. 2011). Finally, another factor to explore is the suggested role of psychological aspects (the negative social perception of the environment) closing the feedback loop and reinforcing the current practices of management. Our findings suggest that this aspect could be an important factor to analyze, and eventually to intervene, such as other authors have suggested in order to break the trap (Scheffer and Westley 2007, Tidball 2016).

According to this, we propose that the inclusion of a resilience system perspective will help to improve theories of socio-technical transitions, in particular the identification of undesirable feedback loops on the social-ecological dynamics of the system, and the identification of constraints exerted at the establishment and consolidation of niches in Latin American cities. Moreover, we suggest that Latin American cities configure a very prone scenario for the emergence of social-ecological urban traps, which can be characterized by the interaction between rigidity and poverty traps, having broader implications for theories of socialecological urban transformations in such a context. This assertion should be analyzed in future studies within a broader set of Latin American cities. 


\section{Escaping traps in Latin America: a challenge for urban social movements?}

Collaborative community-based approaches can be considered as "innovation spaces for bottom-up forms of socially just and environmentally sustainable technological futures" (Smith et al. 2014, as cited in Ramos-Mejía et al. 2018:222). Bottom-up approaches were also considered as potential forms of addressing some of the environmental challenges associated with developing cities (Enqvist et al. 2019). Recently, several authors proposed and analyzed the active role of civil society organizations and social movements to foster sustainability pathways and break socialecological traps in urban contexts (Enqvist 2015, Enqvist et al. 2016, 2019, Frantzeskaki et al. 2016b, Pereira et al. 2018b). We have much to learn in engaging with the diversity of urban social movements in Latin America and their community processes to transform cities (Romero-Lankao and Gnatz 2013, Ruiz-Mallén et al. 2015, Ramos-Mejía et al. 2018).

The need to improve the habitat and to generate better living conditions under adverse political situations has meant that different social movements in several countries of Latin America generate an alliance with academic actors to improve local living conditions (Carruthers 1996, Escobar and Alvarez 2018, Mercon et al. 2018). According to Ramos-Mejía et al. (2018), the process of niche structuring in poverty contexts and institutional configurations typical of the Latin American region rely on (1) community expectations, (2) trespassing political clientelism, (3) shared learning, and (4) the role of social movements as "knowledge intermediaries." Our work validates these mechanisms, although they could not guarantee the effectiveness of the intervention. In our case the proposed transformation collided with the persistence of the trap, which impedes the success of the innovation because of social and environmental restrictions. We agree with Ramos-Mejía et al. (2018) that these are important features to take into account for socio-technical transitions in Latin America, but we also need to think of new ways for escaping traps in these contexts, possibly reconfiguring power balances among actors (Avelino and Rotmans 2011, Romero-Lankao and Gnatz 2013, Boonstra 2016). This is part of the learning outcomes reflected in Table 4. In this sense, the description of a broad kind of social actor interacting locally with the stream, such as educational spaces, may act as a starting point to strength links and networks toward sustainability.

On the other hand, our initiative shows that in order to advance social-ecological transitions in disadvantaged urban contexts, a possible strategy may be the use of public governmental structures that allow for the creation of niches of experimentation or "transformation pockets" (Loorbach et al. 2017, Ramos-Mejía et al. 2018). In our example, the formation of public programs for social cooperatives for the cleaning and sanitation of urban streams was the starting point for the formation of a local niche, which currently continues consolidating despite the shutdown of the original program. Thus, this kind of bottom-up pressure is fundamental, both for the mobilization of governmental resources toward the communities, as well as for the experimentation of alternatives that prefigure other eco-social relations (Elmqvist et al. 2019). Moreover, because of their ability to negotiate with the government, the intermediation of regional grassroots movements becomes fundamental to opening transformative spaces and scaling up experiences to a broader context.

\section{Implications for community-based urban stream ecological management}

Previous studies on ecological stream rehabilitation have remarked on the difficulty of rehabilitating urban streams from an ecosystem-based perspective (Eden and Tunstall 2006, Bernhardt and Palmer 2007, Suren 2009), and our experience concurs. Nevertheless, we think that our approach has some particularities that we want to discuss for a better design of socialecological transformations of urban streams (Zhou et al. 2019). First, we combined quantitative ecological analysis within a social-ecological dynamic framework, which is, in our understanding, one of the first bottom-up attempts to rehabilitate an urban stream from this perspective (e.g., Hager et al. 2013). Typical approaches have relied on purely geomorphic or ecosystem approaches, leaving aside the social context of the landscape (Eden and Tunstall 2006). We want to note the need for an integrative social-ecological perspective to include ecological, social, and political aspects together to design effective approaches for ecological management of urban streams (Palmer 2009, Pickett et al. 2011, Naiman 2013, Martin 2017, Gleick 2018), including a concise evaluation of the process (Nilsson et al. 2016). Using this approach, we found that the survival condition of the reintroduced macrophytes had been affected by a combination of social and environmental processes. Only a joint approach to rehabilitation could possibly manage it: socio-technical advances improving macrophyte retention in urban streams can be used to mitigate hydrological aspects of urban streams (Riis et al. 2009, Basílico et al. 2016); and changes in governance structures should be fostered to improve their survival success (Gleick 2018).

Moreover, the distinction between short- and long-term effects allowed us to analyze processes that could be affecting the survival in different temporal scales (Cash et al. 2006). Indeed, the relative increase in short-term survival (three months) between interventions was in part due to a negotiation process with top hierarchical supervisors related with the governance of the stream. Also, the distinction between short-term and long-term survival enabled us to evaluate other limnological aspects related to the short-term effect of interventions on water quality and early trophic changes (data in preparation), suggesting that at least niche experimentation could benefit from short-term evaluation as a bottom-up pressure to favor long-term changes and help to reconfigure power balance at the local level.

\section{Limitations and challenges of the action-research approach}

The participatory action research framework helped us to conceptualize our work as a colearning process where actors share their knowledge, create new knowledge, and work together to form action plans (Parkes and Panelli 2001). We were able to develop the different main stages of a participatory action research framework: developing a partnership, initial reflection and diagnostic (in this case about the local social-ecological framework), codesigning and coproducing the research, and finally reflection and further planning. Despite this, one of the main limitations we found is related to the dependency of the local actor with respect to the academic one. Although the coproduction of the different aspects of the work was always attempted, we could not consolidate the accomplishment of several activities without relying on our intervention, e.g., the cultivation and transplantation of the aquatic macrophytes. This is one of the aspects to improve in future work. The collaborative development of causal diagram loops is another methodological 
tool to include in future research, considering the level of synthesis obtained from its use, its relative conceptual simplicity, and the existence of many participatory approaches already developed (Videira et al. 2010, Elsawah et al. 2015, Lane and Videira 2019). Last, the socioeconomic background and the power asymmetries between governance actors at the local level implied a difficult context to the everyday work, exerting some limitations fundamentally in terms of the available time of local participants, and available infrastructure. Our challenge is to think about, explore, and promote new forms of coproduction in this context, deepening the execution of fully collaborative processes that consolidate our transforming urban space, enabling the gain of political legitimacy and providing us with resources to overcome this daunting background.

\section{CONCLUSION}

Urban transformation in Latin America requires the growth and consolidation of transformation pockets where alternative governance actions can develop in opposition to the commonly found hierarchical top-down approaches. We explored the establishment of a social-ecological transformative urban space through a collaborative learning approach for the codesign of an ecosystem-based intervention around the management of an urban stream. Through qualitative and quantitative analysis, we conclude that biophysical and social processes related both to institutional and rigidity traps affected the efficacy of the sociotechnical innovation, reflecting the inertia of the current management programs to ecological improvements of the stream. Future work, which we have already begun, should be focused on the consolidation of an extended network of social actors that help to strengthen and make visible our bottom-up approach to other institutional governance actors. The implementation of alternative macrophyte retention devices are also needed to surpass the environmental shortcomings generated by a long history of hydraulic modifications of the landscape. Finally, our findings note the opportunities and challenges triggered to design effective social-ecological transformative actions in alliance with local social movements within a rigidity trap and a sociovulnerable urban context, and the need to tackle such perspectives through a concise evaluation of the efficacy of our actions from a resilient system perspective. Social-ecological urban stream management in Latin America requires all our abilities to break the traps that maintain their undesirable, polluted, and degraded current state.

Responses to this article can be read online at: http://www.ecologyandsociety.org/issues/responses. php/11226

\section{Acknowledgments:}

We wish to thank all members of the Mirabal Cultural Center and FOL organization who relentlessly supported the work beyond the formal work of the cooperative. The work was funded by a grant of the National Agency for the Promotion of Science and Technology of Argentina, PICT 2015-1479.

\section{LITERATURE CITED}

Alberti, M., T. McPhearson, and A. Gonzalez. 2018. Embracing urban complexity. Pages 45-67 in T. Elmqvist, X. Bai, N. Frantzeskaki, C. Griffith, D. Maddox, T. McPhearson, S. Parnell, P. Romero-Lankao, D. Simon, and M. Watkins, editors. Urban planet: knowledge towards sustainable cities. First edition. Cambridge University Press, Cambridge, UK. https://doi. org/10.1017/9781316647554.004

Angelstam, P., M. Grodzynskyi, K. Andersson, R. Axelsson, M. Elbakidze, A. Khoroshev, I. Kruhlov, and V. Naumov. 2013. Measurement, collaborative learning and research for sustainable use of ecosystem services: landscape concepts and Europe as laboratory. Ambio 42(2):129-145. https://doi.org/10.1007/ s13280-012-0368-0

Anton, D. J. 1993. Thirsty cities. Urban environments and water supply in Latin America. First edition. International Development Research Centre, Ottawa, Ontario, Canada.

Avelino, F., and J. Rotmans. 2011. A dynamic conceptualization of power for sustainability research. Journal of Cleaner Production 19(8):796-804. https://doi.org/10.1016/j.jclepro.2010.11.012

Baker, D. M., G. Murray, and A. K. Agyare. 2018. Governance and the making and breaking of social-ecological traps. Ecology and Society 23(1):38. https://doi.org/10.5751/ES-09992-230138

Basco-Carrera, L., A. Warren, E. van Beek, A. Jonoski, and A. Giardino. 2017. Collaborative modelling or participatory modelling? A framework for water resources management. Environmental Modelling \& Software 91:95-110. https://doi. org/10.1016/j.envsoft.2017.01.014

Basílico, G., L. de Cabo, A. Faggi, and S. Miguel. 2016. Low-tech alternatives for the rehabilitation of aquatic and riparian environments. Pages 349-364 in A. A. Ansari, S. Singh Gill, R. Gill, G. R. Lanza, and L. Newman, editors. Phytoremediation: management of environmental contaminants. Volume 4. Springer, Cham, Switzerland. https://doi.org/10.1007/978-3-319-41811-7 18

Bennett, E. M., M. Solan, R. Biggs, T. McPhearson, A. V. Norstrom, P. Olsson, L. Pereira, G. D. Peterson, C. RaudseppHearne, F. Biermann, S. R. Carpenter, E. C. Ellis, T. Hichert, V. Galaz, M. Lahsen, M. Milkoreit, B. M. Lopez, K. A. Nicholas, R. Preiser, G. Vince, J. M. Vervoort, and J. Xu. 2016. Bright spots: seeds of a good Anthropocene. Frontiers in Ecology and the Environment 14(8):441-448. https://doi.org/10.1002/fee.1309

Bernhardt, E. S., and M. A. Palmer. 2007. Restoring streams in an urbanizing world. Freshwater Biology 52(4):738-751. https:// doi.org/10.1111/j.1365-2427.2006.01718.X

Bivand, R. S., E. Pebesma, and V. Gomez-Rubio. 2013. Applied spatial data analysis with $R$. Second edition. Springer, New York, New York, USA. https://doi.org/10.1007/978-1-4614-7618-4

Boonstra, W. J. 2016. Conceptualizing power to study socialecological interactions. Ecology and Society 21(1):21. https://doi. org/10.5751/ES-07966-210121

Boonstra, W. J., and F. W. De Boer. 2014. The historical dynamics of social-ecological traps. Ambio 43(3):260-274. https://doi. org/10.1007/s13280-013-0419-1 
Bowles, S., S. N. Durlauf, and K. R. Hoff. 2011. Poverty traps. Princeton University Press, Princeton, New Jersey, USA. https:// doi.org/10.1515/9781400841295

Brown, K. 2016. Traps and transformations: the resilience of poverty. Pages 156-183 in K. Brown, editor. Resilience, development and global change. Routledge, New York, New York, USA.

Cabrera, A. L., and H. A. Fabris. 1948. Plantas Acuáticas de la Provincia de Buenos Aires. Dirección Agropecuaria, Taller de Impresiones Oficiales, La Plata, Argentina.

Capítulo, A. R., N. Gómez, A. Giorgi, and C. Feijoó. 2010. Global changes in pampean lowland streams (Argentina): implications for biodiversity and functioning. Hydrobiologia 657(1):53-70. https://doi.org/10.1007/s10750-010-0319-3

Capps, K. A., C. N. Bentsen, and A. Ramírez. 2016. Poverty, urbanization, and environmental degradation: urban streams in the developing world. Freshwater Science 35(1):429-435. https:// doi.org/10.1086/684945

Carpenter, S. R., and W. A. Brock. 2008. Adaptive capacity and traps. Ecology and Society 13(2):40. https://doi.org/10.5751/ ES-02716-130240

Carruthers, D. V. 1996. Indigenous ecology and the politics of linkage in Mexican social movements. Third World Quarterly 17 (5)1007-1028. https://doi.org/10.1080/01436599615236

Cash, D. W., W. Adger, F. Berkes, P. Garden, L. Lebel, P. Olsson, L. Pritchard, and O. Young. 2006. Scale and cross-scale dynamics: governance and information in a multilevel world. Ecology and Society 11(2):8. https://doi.org/10.5751/ES-01759-110208

Castañé, P. M., M. G. Rovedatti, M. L. Topalián, and A. Salibián. 2006. Spatial and temporal trends of physicochemical parameters in the water of the Reconquista River (Buenos Aires, Argentina). Environmental Monitoring and Assessment 117(1-3):135-144. https://doi.org/10.1007/s10661-006-7980-Z

Chapin III, F. S., C. Folke, and G. P. Kofinas. 2009. A framework for understanding change. Page 3-28 in C. Folke, G. P. Kofinas, and F. S. Chapin, editors. Principles of ecosystem stewardship. First edition. Springer, New York, New York, USA. https://doi. org/10.1007/978-0-387-73033-2 1

Chevalier, J. M., and D. J. Buckles. 2013. Participatory action research: theory and methods for engaged inquiry. Routledge, London, UK. https://doi.org/10.4324/9781351033268

Child Hill, R., and K. Fujita. 2003. The nested city: introduction. Urban Studies 40(2):207-217. https://doi.org/10.1080/00420980220080251

Cinner, J. E. 2009. Poverty and the use of destructive fishing gear near east African marine protected areas. Environmental Conservation 36(4):321-326. https://doi.org/10.1017/S0376892910000123

Cirelli, A. F., and C. Ojeda. 2008. Wastewater management in Greater Buenos Aires, Argentina. Desalination 218(1-3):52-61. https://doi.org/10.1016/j.desal.2006.10.040

Cortelezzi, A., M. V. Sierra, N. Gómez, C. Marinelli, and A. Rodrigues Capítulo. 2012. Macrophytes, epipelic biofilm, and invertebrates as biotic indicators of physical habitat degradation of lowland streams (Argentina). Environmental Monitoring and Assessment 185(7):5801-5815. https://doi.org/10.1007/s10661-012-2985-2
Cox, M. 2016. The pathology of command and control: a formal synthesis. Ecology and Society 21(3):33. https://doi.org/10.5751/ ES-08698-210333

Cumming, G. S. 2018. A review of social dilemmas and socialecological traps in conservation and natural resource management. Conservation Letters 11(1):e12376. https://doi. org/10.1111/conl.12376

Eden, S. E., and S. Tunstall. 2006. Ecological versus social restoration? How urban river restoration challenges but also fails to challenge the science-policy nexus in the United Kingdom. Environment and Planning C: Government and Policy 24 (5):661-680. https://doi.org/10.1068/c0608j

Efron, S. T. 2015. Hacia la rehabilitación ecológica de un arroyo urbano: una experiencia de investigación-acción en el arroyo San Francisco. Thesis. Universidad de Buenos Aires, Argentina.

Efron, S. T., J. Aquino, L. de Cabo, M. dos Santos Afonso, and M. Graziano. 2014. Evaluación de la capacidad de autodepuración de un arroyo urbano y el uso de macrófitas nativas como estrategia de restauración. Biología Acuática 30:275-285.

Elmqvist, T., E. Andersson, N. Frantzeskaki, T. McPhearson, P. Olsson, O. Gaffney, K. Takeuchi, and C. Folke. 2019. Sustainability and resilience for transformation in the urban century. Nature Sustainability 2:267-273. https://doi.org/10.1038/ s41893-019-0250-1

Elordi, M. L. 2016. Microbiología ambiental: estudio de patógenos asociados a enfermedades hídricas en arroyos urbanos bonaerenses. Índices de calidad y contaminación del agua. Influencia en la salud de la población adyacente. Dissertation. National University of La Plata, Buenos Aires, Argentina. https://doi.org/10.35537/10915/53609

Elsawah, S., J. H. A. Guillaume, T. Filatova, J. Rook, and A. J. Jakeman. 2015. A methodology for eliciting, representing, and analysing stakeholder knowledge for decision making on complex socio-ecological systems: from cognitive maps to agent-based models. Journal of Environmental Management 151:500-516. https://doi.org/10.1016/j.jenvman.2014.11.028

Enfors, E. 2013. Social-ecological traps and transformations in dryland agro-ecosystems: using water system innovations to change the trajectory of development. Global Environmental Change 23(1):51-60. https://doi.org/10.1016/j.gloenvcha.2012.10.007

Enfors, E. I., and L. J. Gordon. 2008. Dealing with drought: the challenge of using water system technologies to break dryland poverty traps. Global Environmental Change 18(4):607-616. https://doi.org/10.1016/j.gloenvcha.2008.07.006

Enqvist, J. 2015. Urban environmental stewardship: roles and reasons for civic engagements in governance of social-ecological systems. Thesis. Stockholm Resilience Centre, Stockholm University, Sweden.

Enqvist, J. P., M. Tengö, and Ö. Bodin. 2019. Are bottom-up approaches good for promoting social-ecological fit in urban landscapes? Ambio 1-13. https://doi.org/10.1007/s13280-019-01163-4

Enqvist, J., M. Tengö, and W. J. Boonstra. 2016. Against the current: rewiring rigidity trap dynamics in urban water governance through civic engagement. Sustainability Science 11 (6):919-933. https://doi.org/10.1007/s11625-016-0377-1 
Escobar, A., and S. E. Alvarez. 2018. The making of social movements in Latin America. Routledge, New York, New York, USA. https://doi.org/10.4324/9780429496301

Feijoó, C. S., and R. J. Lombardo. 2007. Baseline water quality and macrophyte assemblages in Pampean streams: a regional approach. Water Research 41(7):1399-1410. https://doi. org/10.1016/j.watres.2006.08.026

Frantzeskaki, N., M. Bach, and P. Mguni. 2018. Understanding the urban context and its challenges. Pages 43-61 in $\mathrm{N}$. Frantzeskaki, K. Hölscher, M. Bach, and F. Avelino, editors. Cocreating sustainable urban futures. First edition. Springer, Cham, Switzerland. https://doi.org/10.1007/978-3-319-69273-9 2

Frantzeskaki, N., A. Dumitru, I. Anguelovski, F. Avelino, M. Bach, B. Best, C. Binder, J. Barnes, G. Carrus, M. Egermann, A. Haxeltine, M.-L. Moore, R. G. Mira, D. Loorbach, D. Uzzell, I. Omman, P. Olsson, G. Silvestri, R. Stedman, J. Wittmayer, R. Durrant, and F. Rauschmayer. 2016b. Elucidating the changing roles of civil society in urban sustainability transitions. Current Opinion in Environmental Sustainability 22:41-50. https://doi. org/10.1016/j.cosust.2017.04.008

Frantzeskaki, N., N. Kabisch, and T. McPhearson. $2016 a$. Advancing urban environmental governance: understanding theories, practices and processes shaping urban sustainability and resilience. Environmental Science \& Policy 62:1-6. https://doi. org/10.1016/j.envsci.2016.05.008

FREPLATA. 2004. Análisis diagnóstico transfronterizo del Río de la Plata y su frente marítimo. Technical report. Proyecto Protección Ambiental del Río de la Plata y su Frente Marítimo. Programa de las Naciones Unidas para el Desarrollo (PNUD), Oficinas Regionales de Montevideo y Buenos Aires, Argentina.

Fuenfschilling, L., N. Frantzeskaki, and L. Coenen. 2018. Urban experimentation \& sustainability transitions. European Planning Studies 27(2):219-228. https://doi.org/10.1080/09654313.2018.1532977

Giorgi, A., C. Feijoó, and G. Tell. 2005. Primary producers in a Pampean stream: temporal variation and structuring role. Biodiversity \& Conservation 14(7):1699-1718. https://doi. org/10.1007/s10531-004-0694-Z

Gleick, P. H. 2018. Transitions to freshwater sustainability. Proceedings of the National Academy of Sciences 115 (36):8863-8871. https://doi.org/10.1073/pnas.1808893115

Groffman, P. M., J. Cavender-Bares, N. D. Bettez, J. M. Grove, S. J. Hall, J. B. Heffernan, S. E. Hobbie, K. L. Larson, J. L. Morse, C. Neill, K. Nelson, J. O'Neil-Dunne, L. Ogden, D. E. Pataki, C. Polsky, R. R. Chowdhury, and M. K. Steele. 2014. Ecological homogenization of urban USA. Frontiers in Ecology and the Environment 12(1):74-81. https://doi.org/10.1890/120374

Guida Johnson, B., J. Schnellinger, A. Faggi, A. Voigt, and J. Breuste. 2015. Environmental perception among residents of a polluted watershed in Buenos Aires. Journal of Urban Planning and Development 141(3):A5014002. https://doi.org/10.1061/(asce) up.1943-5444.0000250

Hager, G. W., K. T. Belt, W. Stack, K. Burgess, J. M. Grove, B. Caplan, M. Hardcastle, D. Shelley, S. T. A. Pickett, and P. M. Groffman. 2013. Socioecological revitalization of an urban watershed. Frontiers in Ecology and the Environment 11(1):28-36. https://doi.org/10.1890/120069

Haider, L. J., W. J. Boonstra, G. D. Peterson, and M. Schlüter. 2018. Traps and sustainable development in rural areas: a review. World Development 101:311-321. https://doi.org/10.1016/j. worlddev.2017.05.038

Hänke, H., J. Barkmann, C. Coral, E. Enfors Kaustky, and R. Marggraf. 2017. Social-ecological traps hinder rural development in southwestern Madagascar. Ecology and Society 22(1):42. https://doi.org/10.5751/ES-09130-220142

Hardoy, J., and G. Pandiella. 2009. Urban poverty and vulnerability to climate change in Latin America. Environment and Urbanization 21(1):203-224. https://doi.org/10.1177/0956247809103019

Herringshaw, C. J., J. R. Thompson, and T. W. Stewart. 2010. Learning about restoration of urban ecosystems: a case study integrating public participation, stormwater management, and ecological research. Urban Ecosystems 13(4):535-562. https://doi. org/10.1007/s11252-010-0134-7

Holling, C. S., and G. K. Meffe. 1996. Command and control and the pathology of natural resource management. Conservation Biology 10(2):328-337. https://doi.org/10.1046/j.1523-1739.1996.10020328. $\underline{\mathrm{X}}$

Instituto Nacional de Estadística y Censos (INDEC). 2010. Censo nacional de población, hogares y viviendas. INDEC, Buenos Aires, Argentina. [online] URL: https://www.indec.gob.ar/indec/web/ Nivel4-Tema-2-41-135

Källström, H. N., and M. Ljung. 2005. Social sustainability and collaborative learning. Ambio 34(4):376-382. https://doi. org/10.1579/0044-7447-34.4.376

Knieper, C., and C. Pahl-Wostl. 2016. A comparative analysis of water governance, water management, and environmental performance in river basins. Water Resources Management 30 (7):2161-2177. https://doi.org/10.1007/s11269-016-1276-Z

Laborde, S., A. Fernández, S. C. Phang, I. M. Hamilton, N. Henry, H. C. Jung, A. Mahamat, M. Ahmadou, B. K. Labara, S. Kari, M. Durand, B. Mark, P. Scholte, N. Xiao, R. Ziebe, and M. Moritz. 2016. Social-ecological feedbacks lead to unsustainable lock-in in an inland fishery. Global Environmental Change 41:13-25. https://doi.org/10.1016/j.gloenvcha.2016.08.004

Lane, D. C., and N. Videira. 2019. Modelling sustainability pathways: bridging science, policy, and society. Systems Research and Behavioral Science 36(2):147-155. https://doi.org/10.1002/ sres. 2586

Larned, S. T., A. M. Suren, M. Flanagan, B. J. F. Biggs, and T. Riis. 2006. Macrophytes in urban stream rehabilitation: establishment, ecological effects, and public perception. Restoration Ecology 14(3):429-440. https://doi.org/10.1111/ j.1526-100X.2006.00151.X

Lebel, L., J. B. Manuta, and P. Garden. 2011. Institutional traps and vulnerability to changes in climate and flood regimes in Thailand. Regional Environmental Change 11(1):45-58. https:// doi.org/10.1007/s10113-010-0118-4 
Loorbach, D., N. Frantzeskaki, and F. Avelino. 2017. Sustainability transitions research: transforming science and practice for societal change. Annual Review of Environment and Resources 42:599-626. https://doi.org/10.1146/annurevenviron-102014-021340

Ludwig, D. 2001. The era of management is over. Ecosystems 4 (8):758-764. https://doi.org/10.1007/s10021-001-0044-X

Magdaleno, A., A. Puig, L. De Cabo, C. Salinas, S. Arreghini, S. Korol, S. Bevilacqua, L. López, and J. Moretton. 2001. Water pollution in an urban Argentine river. Bulletin of Environmental Contamination and Toxicology 67(3):408-415. https://doi. org/10.1007/s001280139

Martin, D. M. 2017. Ecological restoration should be redefined for the twenty-first century. Restoration Ecology 25(5):668-673. https://doi.org/10.1111/rec.12554

Mathur, M. 2015. Spatial autocorrelation analysis in plant population: an overview. Journal of Applied and Natural Science 7(1):501-513. https://doi.org/10.31018/jans.v7i1.639

Mercon, J., J. A. Rosell, B. Ayala-Orozco, I. Bueno, A. Lobato, and G. Alatorre Frenk. 2018. Colaboración transdiciplinaria para la sustentabilidad en México: principales retos y estrategias. Pages 27-57 in L. G. Rodríguez Zoya and S. Colmenero, editors. Experiencias de colaboración transdisciplinaria para la sustentabilidad. First edition. Comunidad Editora Latinoamericana, Ciudad Autónoma de Buenos Aires, Argentina.

Merlinsky, M. G., S. Fernández Bouzo, C. Montera, and M. Tobías. 2012. Social inequality, environmental justice and water policy in Buenos Aires. Rethinking Devolopment \& Inequality 1:49-59.

Middleton, J. V. 2001. The stream doctor project: communitydriven stream restoration. BioScience 51(4):293-296. https://doi. org/10.1641/0006-3568(2001)051[0293:TSDPCD]2.0.CO;2

Moore, M.-L., O. Tjornbo, E. Enfors, C. Knapp, J. Hodbod, J. A. Baggio, A. Norström, P. Olsson, and D. Biggs. 2014. Studying the complexity of change: toward an analytical framework for understanding deliberate social-ecological transformations. Ecology and Society 19(4):54. https://doi.org/10.5751/ES-06966-190454

Naiman, R. J. 2013. Socio-ecological complexity and the restoration of river ecosystems. Inland Waters 3(4):391-410. https://doi.org/10.5268/iw-3.4.667

Natalucci, A. L. 2012. Social politics and territorial quarrels. A case study on the "Argentina Works" program. Revista Perspectivas de Políticas Públicas 2(3):126-147.

Nilsson, C., A. L. Aradottir, D. Hagen, G. Halldórsson, K. Høegh, R. J. Mitchell, K. Raulund-Rasmussen, K. Svavarsdóttir, A. Tolvanen, and S. D. Wilson. 2016. Evaluating the process of ecological restoration. Ecology and Society 21(1):41. https://doi. org/10.5751/ES-08289-210141

Öberg, G., M. G. Merlinsky, A. LaValle, M. Morales, and M. M. Tobias. 2014. The notion of sewage as waste: a study of infrastructure change and institutional inertia in Buenos Aires, Argentina and Vancouver, Canada. Ecology and Society 19(2):19. https://doi.org/10.5751/ES-06531-190219
Olsson, P., C. Folke, and F. Berkes. 2004. Adaptive comanagement for building resilience in social-ecological systems. Environmental Management 34(1):75-90. https://doi.org/10.1007/s00267-003-0101-7

Olsson, P., L. H. Gunderson, S. R. Carpenter, P. Ryan, L. Lebel, C. Folke, and C. S. Holling. 2006. Shooting the rapids: navigating transitions to adaptive governance of social-ecological systems. Ecology and Society 11(1):18. https://doi.org/10.5751/ES-01595-110118

Palmer, M. A. 2009. Reforming watershed restoration: science in need of application and applications in need of science. Estuaries and Coasts 32(1):1-17. https://doi.org/10.1007/s12237-008-9129-5

Palmer, M., J. D. Allan, J. Meyer, and E. S. Bernhardt. 2007. River restoration in the twenty-first century: data and experiential knowledge to inform future efforts. Restoration Ecology 15 (3):472-481. https://doi.org/10.1111/j.1526-100x.2007.00243.x

Palmer, M. A., K. L. Hondula, and B. J. Koch. 2014. Ecological restoration of streams and rivers: shifting strategies and shifting goals. Annual Review of Ecology, Evolution, and Systematics 45:247-269. https://doi.org/10.1146/annurev-ecolsys-120213-091935

Parkes, M., and R. Panelli. 2001. Integrating catchment ecosystems and community health: the value of participatory action research. Ecosystem Health 7(2):85-106. https://doi. org/10.1046/j.1526-0992.2001.007002085.x

Paz, L. E., M. M. Nicolosi Gelis, M. Licursi, N. Gómez, and A. Rodrigues Capítulo. 2018. Use of native macrophytes for recovery of the habitat structure and complexity of a lowland stream affected by river engineering works: implications for management. River Research and Applications 34(6):575-585. https://doi.org/10.1002/rra.3280

Peipoch, M., M. Brauns, F. R. Hauer, M. Weitere, and H. M. Valett. 2015. Ecological simplification: human influences on riverscape complexity. BioScience 65(11):1057-1065. https://doi. org/10.1093/biosci/biv120

Pereira, L. M., E. Bennett, R. (O.) Biggs, G. Peterson, T. McPhearson, A. Norström, P. Olsson, R. Preiser, C. RaudseppHearne, and J. Vervoort. 2018a. Seeds of the future in the present: exploring pathways for navigating towards "good" Anthropocenes. Pages 327-350 in T. Elmqvist, X. Bai, N. Frantzeskaki, C. Griffith, D. Maddox, T. McPhearson, S. Parnell, P. Romero-Lankao, D. Simon, and M. Watkins, editors. Urban planet: knowledge towards sustainable cities. Camdbridge University Press, Cambridge, UK. https://doi.org/10.1017/9781316647554.018

Pereira, L. M., T. Karpouzoglou, N. Frantzeskaki, and P. Olsson. 2018b. Designing transformative spaces for sustainability in social-ecological systems. Ecology and Society 23(4):32. https:// doi.org/10.5751/es-10607-230432

Pereyra, S., G. J. Pérez, and F. L. Schuster. 2015. Trends of social protest in Argentina: 1989-2007. Pages 335-360 in P. Almeida and A. Cordero Ulate, editors. Handbook of social movements across Latin America. Springer, Dordrecht, The Netherlands. https:// doi.org/10.1007/978-94-017-9912-6 24

Pickett, S. T. A., G. L. Buckley, S. S. Kaushal, and Y. Williams. 2011. Social-ecological science in the humane metropolis. Urban Ecosystems 14(3):319-339. https://doi.org/10.1007/s11252-011-0166-7 
Purcell, A. H., C. Friedrich, and V. H. Resh. 2002. An assessment of a small urban stream restoration project in Northern California. Restoration Ecology 10(4):685-694. https://doi. org/10.1046/j.1526-100X.2002.01049.X

R Team Core. 2018. R: A language and environment for statistical computing. Foundation for Statistical Computing, Vienna, Austria.

Ramos-Mejía, M., M.-L. Franco-Garcia, and J. M. JaureguiBecker. 2018. Sustainability transitions in the developing world: challenges of socio-technical transformations unfolding in contexts of poverty. Environmental Science \& Policy 84:217-223. https://doi.org/10.1016/j.envsci.2017.03.010

Reyers, B., C. Folke, M.-L. Moore, R. Biggs, and V. Galaz. 2018. Social-ecological systems insights for navigating the dynamics of the Anthropocene. Annual Review of Environment and Resources 43:267-289. https://doi.org/10.1146/annurev-environ-110615-085349

Riis, T., R. Schultz, H. M. Olsen, and C. K. Katborg. 2009. Transplanting macrophytes to rehabilitate streams: experience and recommendations. Aquatic Ecology 43(4):935-942. https:// doi.org/10.1007/s10452-008-9213-8

Rocha, J. C., M. Baraibar, L. Deutsch, A. de Bremond, J. Oestreicher, F. Rositano, and C. Gelabert. 2019. Toward understanding the dynamics of land change in Latin America: potential utility of a resilience approach for building archetypes of land. Ecology and Society 24(1):17. https://doi.org/10.5751/ ES-10349-240117

Romero-Lankao, P., and D. M. Gnatz. 2013. Exploring urban transformations in Latin America. Current Opinion in Environmental Sustainability 5(3-4):358-367. https://doi.org/10.1016/ j.cosust.2013.07.008

Rosendahl, J., M. A. Zanella, S. Rist, and J. Weigelt. 2015. Scientists' situated knowledge: strong objectivity in transdisciplinarity. Futures 65:17-27. https://doi.org/10.1016/j.futures.2014.10.011

Ruiz-Mallén, I., C. Schunko, E. Corbera, M. Rös, and V. ReyesGarcía. 2015. Meanings, drivers, and motivations for communitybased conservation in Latin America. Ecology and Society 20 (3):33. https://doi.org/10.5751/ES-07733-200333

Scheffer, M., and F. R. Westley. 2007. The evolutionary basis of rigidity: locks in cells, minds, and society. Ecology and Society 12 (2):36. https://doi.org/10.5751/ES-02275-120236

Scheinsohn, M., and C. Cabrera. 2009. Social movements and the production of housing in Buenos Aires; when policies are effective. Environment and Urbanization 21(1):109-125. https:// doi.org/10.1177/0956247809103007

Sterman, J. D. 2000. Business dynamics: systems thinking and modeling for a complex world. Irwin/McGraw-Hill, Boston, Massachusetts, USA.

Stringer, L. C., A. J. Dougill, E. Fraser, K. Hubacek, C. Prell, and M. S. Reed. 2006. Unpacking "participation" in the adaptive management of social-ecological systems: a critical review. Ecology and Society 11(2):39. https://doi.org/10.5751/es-01896-110239

Suren, A. M. 2009. Using macrophytes in urban stream rehabilitation: a cautionary tale. Restoration Ecology 17 (6):873-883. https://doi.org/10.1111/j.1526-100X.2008.00446.X
Svampa, M., and S. Pereyra. 2003. Entre la ruta y el barro. Third edition. Editorial Biblos, Buenos Aires, Argentina.

Tidball, K. G. 2016. Traps in and of our minds: relationships between human logic, dialectical traps and social-ecological traps. Sustainability Science 11(6):867-876. https://doi.org/10.1007/ s11625-016-0396-y

Van Driesch, R., and T. Center. 2013. Biological control of invasive plants in protected areas. Pages 561-597 in L. C. Foxcroft, P. Pyšek, D. M. Richardson, and P. Genovesi, editors. Plan invasions in protected areas. Springer Science \& Business Media, Dordrecht, The Netherlands. https://doi.org/10.1007/978-94-007-7750-7 26

van Kerkhoff, L. E., and L. Lebel. 2015. Coproductive capacities: rethinking science-governance relations in a diverse world. Ecology and Society 20(1):14. https://doi.org/10.5751/ES-07188-200114

van Welie, M. J., and H. A. Romijn. 2018. NGOs fostering transitions towards sustainable urban sanitation in low-income countries: insights from transition management and development studies. Environmental Science \& Policy 84:250-260. https://doi. org/10.1016/j.envsci.2017.08.011

Videira, N., P. Antunes, R. Santos, and R. Lopes. 2010. A participatory modelling approach to support integrated sustainability assessment processes. System Research and Behavioral Science 27(4):446-460. https://doi.org/10.1002/ sres.1041

Vilches, C., A. Giorgi, M. Mastrángelo, and L. Ferrari. 2011. Non-point contamination homogenizes the water quality of pampean streams. Bulletin of Environmental Contamination and Toxicology 87(2):147-151. https://doi.org/10.1007/s00128-011-0312-1

Walker, B. H., L. H. Gunderson, A. P. Kinzig, C. Folke, S. R. Carpenter, and L. Schultz. 2006. A handful of heuristics and some propositions for understanding resilience in social-ecological systems. Ecology and Society 11(1):13. https://doi.org/10.5751/ ES-01530-110113

Walsh, C. J., A. H. Roy, J. W. Feminella, P. D. Cottingham, P. M. Groffman, R. P. Morgan II. 2005. The urban stream syndrome: current knowledge and the search for a cure. Freshwater Science 24(3):706-723. https://doi.org/10.1899/04-028.1

Webb, R., X. Bai, M. Stafford Smith, R. Costanza, D. Griggs, M. Moglia, M. Neuman, P. Newman, P. Newton, B. Norman, C. Ryan, H. Schandl, W. Steffen, N. Tapper, and G. Thomson. 2018. Sustainable urban systems: co-design and framing for transformation. Ambio 47(1):57-77. https://doi.org/10.1007/ s13280-017-0934-6

Wieczorek, A. J. 2018. Sustainability transitions in developing countries: major insights and their implications for research and policy. Environmental Science \& Policy 84:204-216. https://doi. org/10.1016/j.envsci.2017.08.008

Woodhouse, P., and M. Muller. 2017. Water governance-an historical perspective on current debates. World Development 92:225-241. https://doi.org/10.1016/j.worlddev.2016.11.014

Zhou, W., B. Fisher, and S. T. A. Pickett. 2019. Cities are hungry for actionable ecological knowledge. Frontiers in Ecology and the Environment 17(3):135-135. https://doi.org/10.1002/fee.2021 


\section{Appendix 1.}

\section{Images of the San Francisco stream}
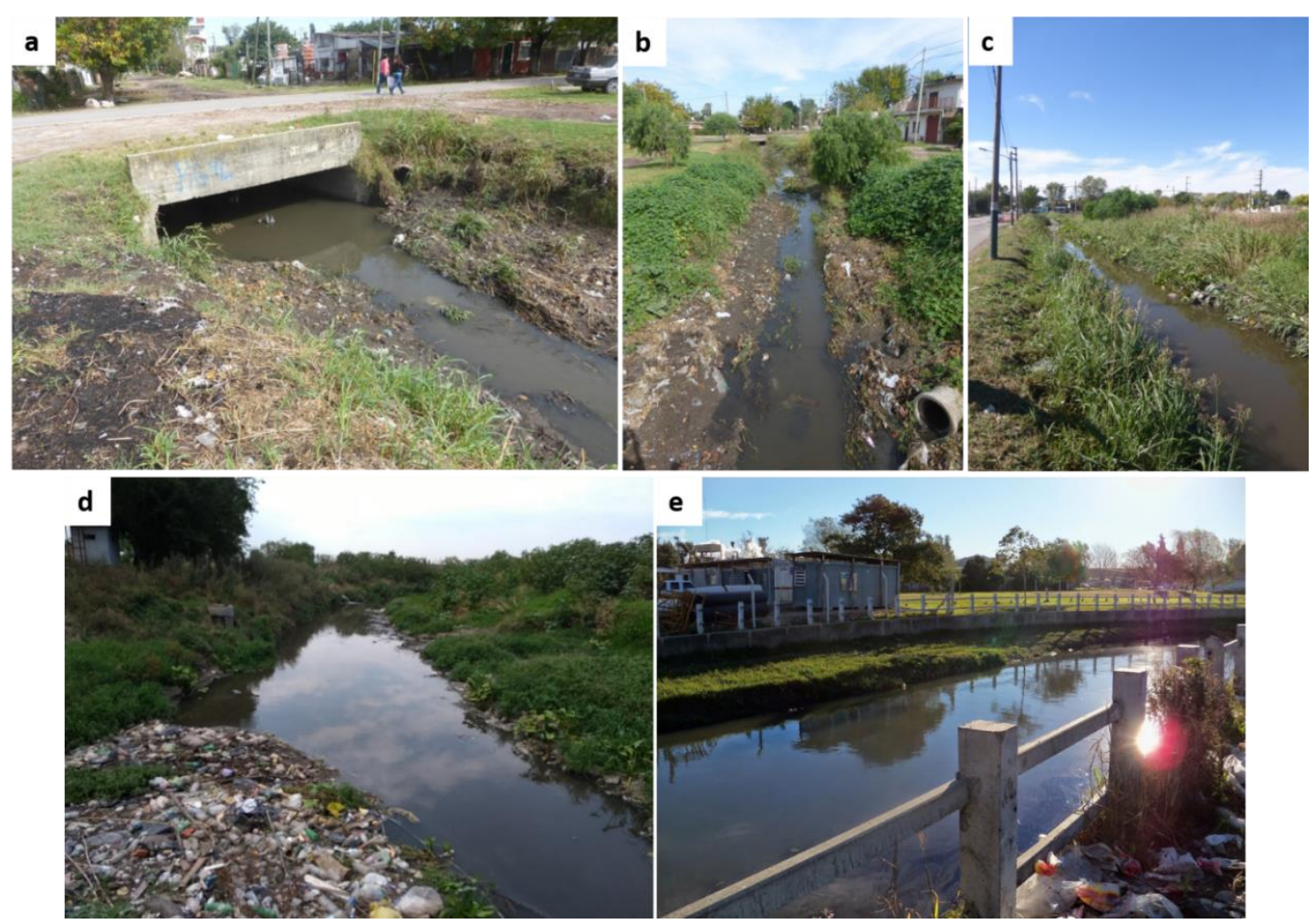

Figure A1.1 Images of the San Francisco stream along its entire course. In A) and B) are depicted images of the headwaters and the emergence to surface at the locality of Claypole (Buenos Aires). Image C) shows part of the stream reach intervened in the work, and D) and E) shows the San Francisco stream near the confluence with Las Piedras stream (Quilmes District), where it can be seen a broader and more degraded stream, with garbage clusters and the presence of concrete structures.

\section{Images of Mirabal Cultural Center}
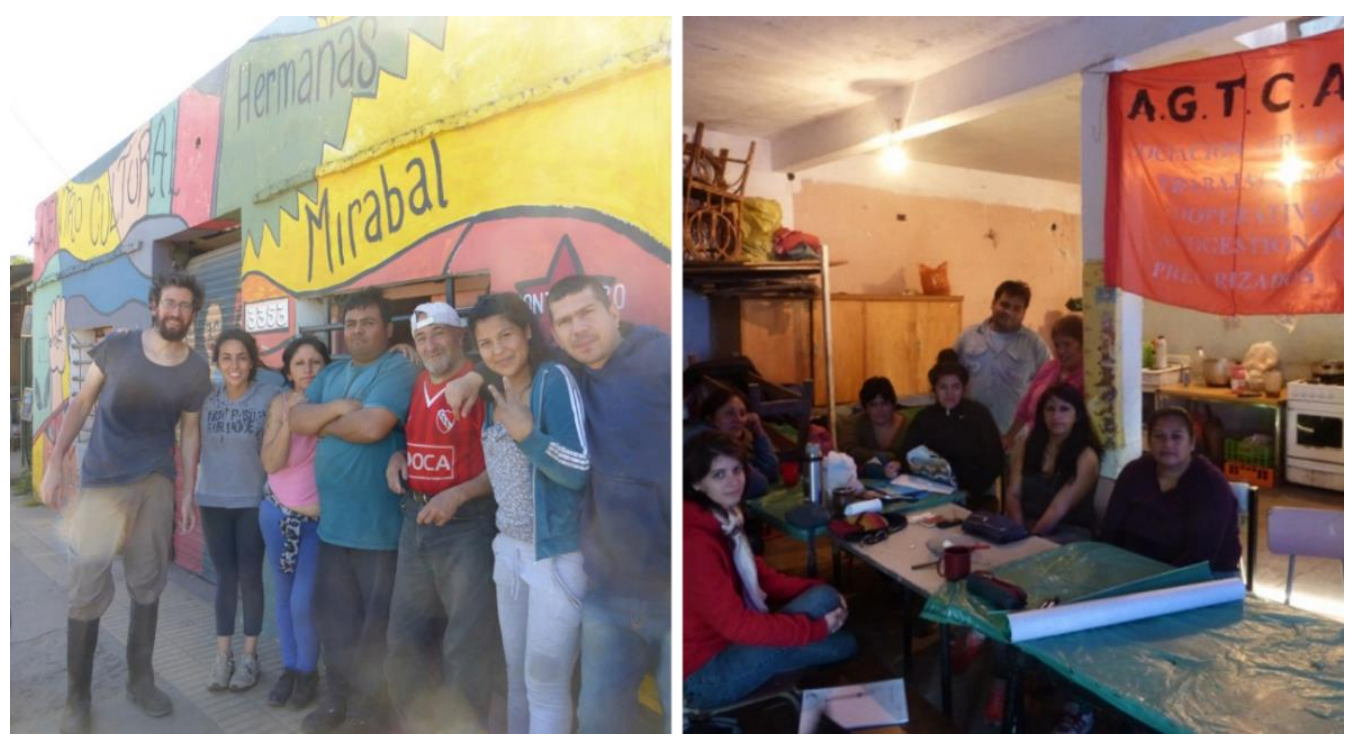

Figure A1.2 Images of the front view of the Mirabal Cultural Center (left), and inside it (right). This cultural center was the place where we carried out the meetings for the implementation of the work. 


\section{Meetings and workshop activities with Mirabal's workers}

During the months of March and April of 2015, we initiate informal visits to the Mirabal Cultural Center with the aim of starting to generate mutual trust between the actors and improve our knowledge about the general work of the organization and specifically the current work of the cooperative workers. The author M.G. had already had contact during the period 2013-2014 with some members of the squad, but it hadn't been the case for the rest of the authors. During the months of May and June we programmed different activities that will be carried out to problematize the current state of the San Francisco stream and to know deeper the perception of the members of the squad about the aquatic environment and its riparian habitat. On May $5^{\text {th }}$, we made a joint visit to the San Francisco stream reach, observing the main channel and the riparian zone and discussing the issues that call our attention. We obtained a list of elements and/or problems (Table A1.1). Then, we met and analyzed those elements trying to decipher their potential harmful to the ecosystem and we began to think about how they could be avoided. In addition, we specify the materials and tools necessary to address those elements linked to the intervention project that were within our reach (i.e., waders, shovels, garden rakes).

\begin{tabular}{|c|}
\hline Presence of trash at the riverbank and the main channel \\
\hline Presence of domestic pipes that drain into the stream through centralized channels \\
\hline Presence of rats \\
\hline Riparian areas without vegetation \\
\hline Low flow velocity \\
\hline Remains of vegetation pruning without recolection
\end{tabular}

Table A1.1 Relevant habitat aspects identified during the field visit at the working stream reach before the beginning of the interventions.

The presence of some cover of aquatic plants and grass on the riverbank was one of the main aspects to be addressed for the ecological management of the stream. The debate on this element made it possible to delineate the management of the riparian vegetation that would be carried out during the intervention, integrating the perception of the members of the squad (and of the neighbors of the neighborhood through them) together with the rehabilitation techniques on the community of macrophytes. In this way, it was agreed to keep the short grass in the middle and upper part of the bank, as an aesthetically important element for the neighborhood, and favor the presence of 
macrophytes in the lower part by a transplantation process, removing the herbaceous plants that could be found there.

A few weeks later, appealing to the historical memory of the people who are part of the squad, a social-ecological reconstruction of the stream was carried out analyzing the transformation of certain aspects from the 90s (and even previously, when they remembered). The aspects addressed included: the morphology of the stream, fauna and flora present, color and transparency of the water, presence of trash, recreational activities, stream management activities (cleaning and maintenance), and frequency of floods. The proposed methodology consisted of a comparative table with three periods: 1970-1990, 1990-2000, 2000-present (Table A1.2).

1990

Currently

\begin{tabular}{|c|c|c|}
\hline Morphology & \multicolumn{2}{|c|}{$\begin{array}{c}\text { it became wider during this period, but the "shape" of the canal was } \\
\text { maintained }\end{array}$} \\
\hline Wildlife fauna & $\begin{array}{l}\text { fish, eels, frogs, tadpoles, } \\
\text { worms, small-size mices }\end{array}$ & $\begin{array}{l}\text { turtles and snakes during } \\
2000 \text { 's, now only rats }\end{array}$ \\
\hline Flora & $\begin{array}{l}\text { Pampean grassland, cattail, } \\
\text { creepers with thorns }\end{array}$ & $\begin{array}{l}\text { grass, water hyacinth, aquatic } \\
\text { plants }\end{array}$ \\
\hline Water color and transparency & \multicolumn{2}{|c|}{$\begin{array}{l}\text { It became more turbid within the period (brown color), whitish at } \\
\text { certain moments }\end{array}$} \\
\hline Garbage & $\begin{array}{l}\text { Prior to } 1990 \text { there was almost } \\
\text { no trash. During the } 90 \text { s the } \\
\text { intensification began }\end{array}$ & Increasing \\
\hline Recreative activities & $\begin{array}{l}\text { Fishing. Recreational space to } \\
\text { play }\end{array}$ & $\begin{array}{l}\text { Nothing recreational, only } \\
\text { extractions of worms for fishing } \\
\text { in other places }\end{array}$ \\
\hline Local Management activities & $\begin{array}{l}\text { There was no maintenance, the } \\
\text { grass grew tall }\end{array}$ & $\begin{array}{l}\text { Greater control and removal of } \\
\text { vegetation, cleaning and } \\
\text { maintenance works emerge }\end{array}$ \\
\hline Flood events & No flood events in this area & $\begin{array}{l}\text { In the last } 3 \text { years the floods } \\
\text { increased notably }\end{array}$ \\
\hline
\end{tabular}

Table A1.2 Social-ecological historical reconstruction of the San Francisco stream at the locality of Claypole (Buenos Aires Province, Argentina).

The social-ecological historical reconstruction of the stream and its transformations from the 90 s to the present presented a negative assessment in relation to the intensification of garbage in the margins and the main channel, an increase in the turbidity of the water, changes in the composition of fauna with a loss of diversity, a strong increase in the periodicity and intensity of floods, and practically the elimination of cultural benefits of the stream habitat such as recreational purposes.

Subsequently, on May 27th we performed a workshop addressing some theoretical aspects, such as the role of macrophytes in water bodies and the importance of 
increasing the diversity of current species, the disadvantages of an excessive pruning in relation with floods, and it also included aspects related to techniques of cultivation and propagation of macrophytes in the greenhouse, practices that would be carried out together to carry out the management interventions. Continuing with the workshop in a following week, we also discussed and identified, based on local knowledge, audio-visual material, journal notes and legal material, the main actors present in the territory, and the functioning and management practices carried out by the current cleaning cooperatives throughout the Metropolitan Area of Buenos Aires (AMBA).

\section{Analysis of motivations}

We performed a workshop session based on a questionnaire of forced-choice options suggested by the academic actor from the previous meetings and expressed in a nonscientific language (Table A1.3). As part of the activity, it was discussed how options could be generalized to values associated with the human being and nature as well as their interrelation, reclassifying them in one of the following categories: aesthetic, sanitary (health), social, ecological, and biocentric (centered in nature, as opposed to anthropocentric aspects).

\begin{tabular}{|l|l|}
\hline \multicolumn{1}{|c|}{ Option } & Valoration category \\
\hline It is not good for our health to live with a stream that is in poor condition & SANITARY \\
\hline Allow us to improve the neighborhood environment working all together & ECO-COMMUNITY \\
\hline It is good to leave the kids a better environment & ECO-COMMUNITY \\
\hline $\begin{array}{l}\text { There were before other living beings (i.e frogs, fishes, turtles) that deserve to } \\
\text { live again in the stream }\end{array}$ & BIOCENTRIC \\
\hline It is not right that nature has been damaged & BIOCENTRIC \\
\hline It provides job opportunities in the neighborhood & SOCIO-COMMUNITY \\
\hline It is not nice to live with a stream that looks ugly & AESTHETIC \\
\hline
\end{tabular}

Table A1.3 List of forced-choice options for the motivation assessment activity and assigned category (sentences translated from Spanish language) 

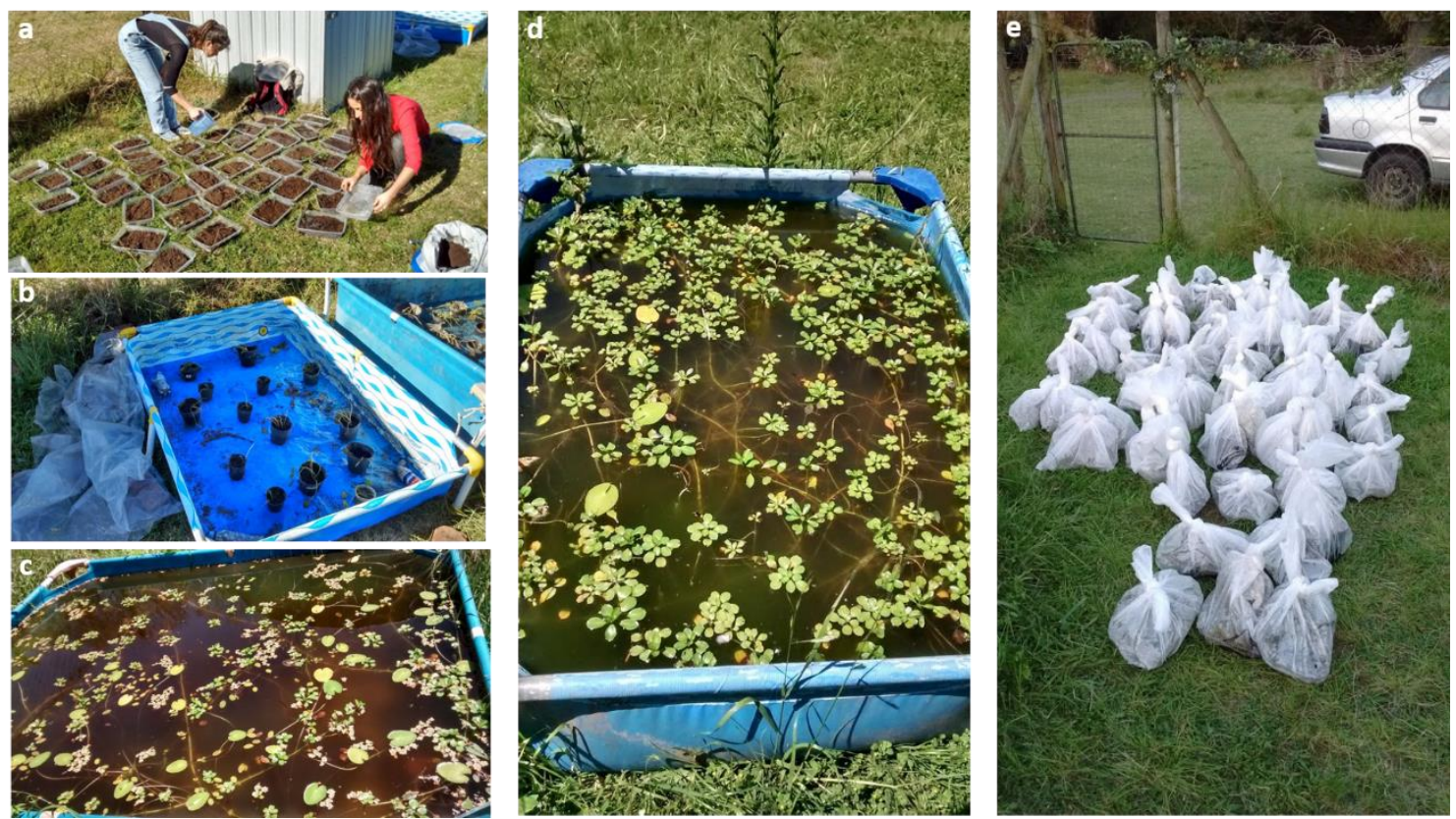

Figure A1.3 Images of the macrophytes cultivation process. In A) and B) are depicted the plastics trays and pots used to delimit experimental units of cultivated macrophytes. Each plastic tray or pot was considered a unique experimental unit. C) and D) shows the growth of experimental units in pools filled with water from the drinking network. E) shows the packaging of each experimental unit for deliver to the working area at the San Francisco stream. 